Temporal and Spatial Distribution of Endangered Juvenile Lost River and Shortnose Suckers in Relation to Environmental Variables in Upper Klamath Lake, Oregon: 2009 Annual Data Summary

Open-File Report 2010-1261 



\section{Temporal and Spatial Distribution of Endangered Juvenile Lost River and Shortnose Suckers in Relation to Environmental Variables in Upper Klamath Lake, Oregon: 2009 Annual Data Summary}

By Jared L. Bottcher and Summer M. Burdick

Open-File Report 2010-1261

U.S. Department of the Interior

U.S. Geological Survey 


\section{U.S. Department of the Interior \\ KEN SALAZAR, Secretary}

\section{U.S. Geological Survey \\ Marcia K. McNutt, Director}

U.S. Geological Survey, Reston, Virginia: 2010

For more information on the USGS-the Federal source for science about the Earth, its natural and living resources, natural hazards, and the environment, visit http://www.usgs.gov or call 1-888-ASK-USGS.

For an overview of USGS information products, including maps, imagery, and publications, visit http://www.usgs.gov/pubprod

To order this and other USGS information products, visit http://store.usgs.gov

Suggested citation:

Bottcher, J.L., and Burdick, S.M., 2010, Temporal and spatial distribution of endangered juvenile Lost River and shortnose suckers in relation to environmental variables in Upper Klamath Lake, Oregon: 2009 annual data summary: U.S. Geological Survey Open-File Report 2010-1261, 42 p.

Any use of trade, product, or firm names is for descriptive purposes only and does not imply endorsement by the U.S. Government.

Although this report is in the public domain, permission must be secured from the individual copyright owners to reproduce any copyrighted material contained within this report. 


\section{Contents}

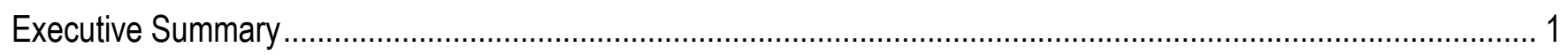

Project Introduction and Background .................................................................................................. 2

Study Area

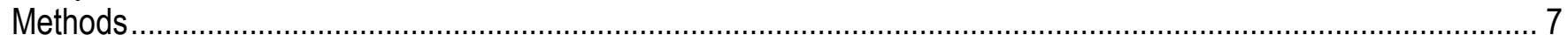

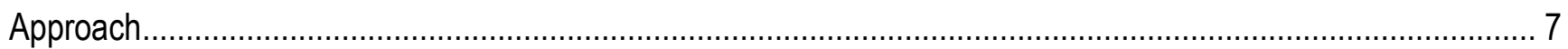

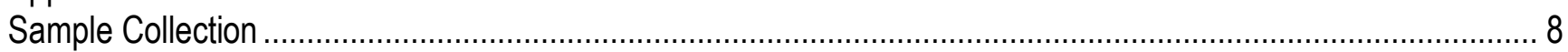

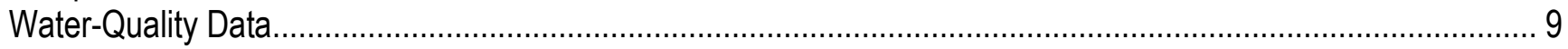

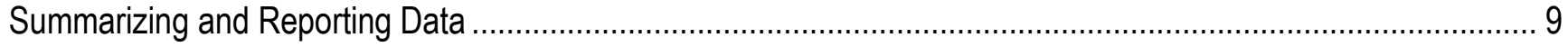

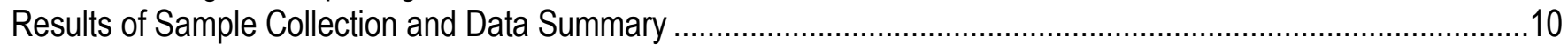

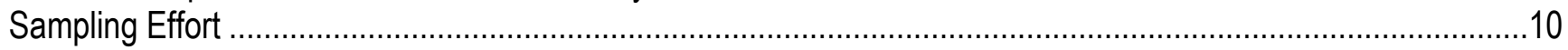

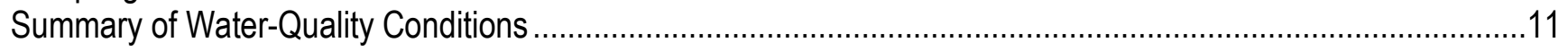

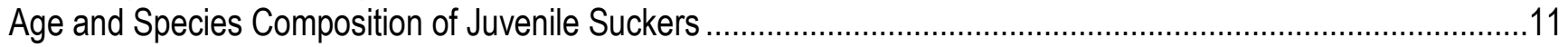

Spatial-Temporal Patterns in Age-1 and Age-2 Sucker Catches.................................................................12

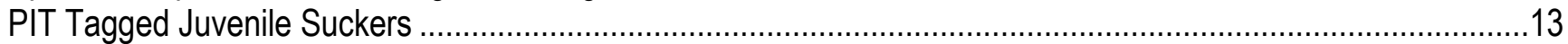

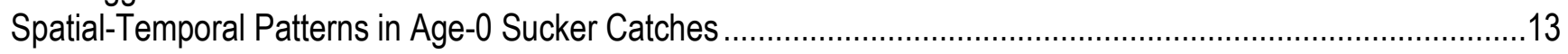

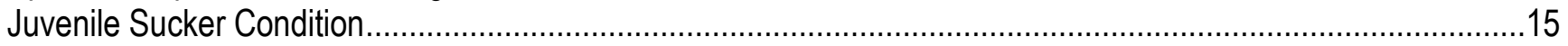

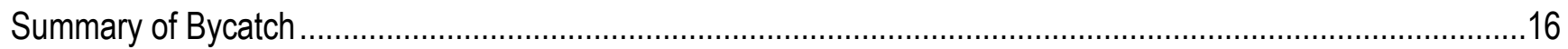

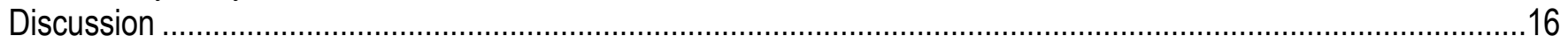

Distribution and Movement of Age-1 and Older Juvenile Suckers ..............................................................16

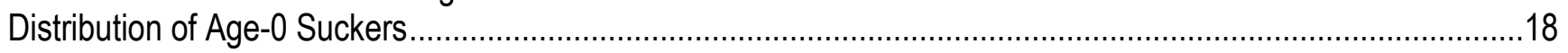

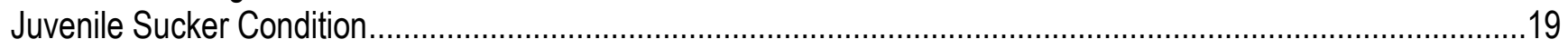

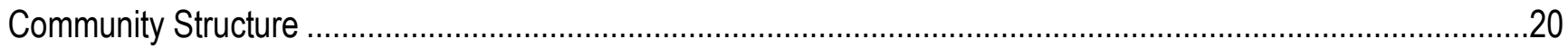

Acknowledgments

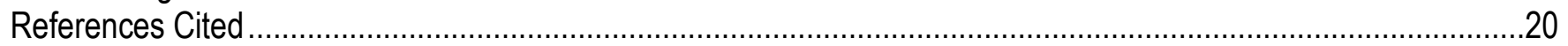

\section{Figures}

Figure 1. Map of Upper Klamath Lake study area and three defined areas of the lake ....................................... 24

Figure 2. Dissolved oxygen concentrations (dotted black) and temperature (solid red) recorded each hour at three water-quality monitoring stations in Upper Klamath Lake, Oregon ......................................... 25

Figure 3. Standard lengths of juvenile suckers caught in trap nets set in Upper Klamath Lake and tributaries

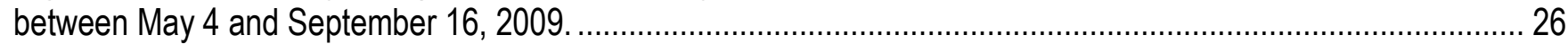

Figure 4. Mean $( \pm S D$ ) weekly catch per unit effort (suckers per net) for age-1 suckers caught in trap nets set overnight in Upper Klamath Lake, Oregon, between May 3 and September 13, 2009.

Figure 5. Mean $( \pm S D$ ) weekly catch per unit effort (suckers per net) for age-1 suckers caught in trap nets set overnight in Upper Klamath Lake, Oregon, and its tributaries, between May 4 and September 16, 2009 .............. 28 Figure 6. Location of sample sites and age-1 and age-2 sucker catch rates in Upper Klamath Lake, Oregon, and its tributaries, by week

Figure 7. Depth for trap net sites (A), sites where age-0 suckers were caught $(B)$, sites where age-1 suckers were caught $(C)$, and sites where age-2 suckers were caught $(D)$ are shown by week.

Figure 8. Mean $( \pm S D$ ) weekly catch per unit effort (suckers per net) for age-0 suckers caught in trap nets set overnight in Upper Klamath Lake, Oregon, between July 12 and September 16, 2009 
Figure 9. Mean ( $\pm S D$ ) weekly catch per unit effort (suckers per net) for age-0 suckers caught in trap nets in three off-shore areas (fig. 1) of Upper Klamath Lake, Oregon, between July 12 and

Figure 10. Mean $( \pm S D$ ) weekly catch per unit effort (suckers per net) for age-0 suckers caught in trap nets in three near-shore areas.

Figure 11. Mean ( \pm SD) catch per unit effort (CPUE: suckers per net) by $1.0 \mathrm{~m}$ depth bins for

age-0 (top) and age-1 (bottom) suckers caught in Upper Klamath Lake, Oregon.

Figure 12. Standard length $(\mathrm{mm})$ of age- 0 suckers caught in trap net sampling in three areas of Upper Klamath Lake, Oregon, between July 12 and September 16, 2009

Figure 13. Mean weekly catch per unit effort (fish per net) of fish other than sucker species captured in trap nets set overnight in three areas of Upper Klamath Lake, Oregon

\section{Tables}

Table 1. Number of sites successfully sampled for juvenile fish in three seasons and in six strata in Upper Klamath Lake, Oregon, 2009

Table 2. Number of nets successfully fished and age-1 and age-2 suckers captured per net in six strata in Upper Klamath Lake, Oregon, between May 17 and September 5, 2009

\section{Conversion Factors, Datum, and Abbreviations and Acronyms}

\section{Conversion Factors}

\begin{tabular}{|c|c|c|}
\hline & & \\
\hline Multiply & By & To obtain \\
\hline \multicolumn{3}{|c|}{ Length } \\
\hline millimeter (mm) & 0.03937 & inch (in.) \\
\hline meter $(\mathrm{m})$ & 3.281 & foot $(\mathrm{ft})$ \\
\hline kilometer (km) & 0.6214 & mile (mi) \\
\hline kilometer (km) & 0.54 & mile, nautical (nmi) \\
\hline meter $(\mathrm{m})$ & 1.094 & yard (yd) \\
\hline \multicolumn{3}{|c|}{ Area } \\
\hline square meter $\left(\mathrm{m}^{2}\right)$ & 0.0002471 & acre \\
\hline square kilometer $\left(\mathrm{km}^{2}\right)$ & 0.3861 & square mile $\left(\mathrm{mi}^{2}\right)$ \\
\hline \multicolumn{3}{|c|}{ Volume } \\
\hline liter (L) & 33.82 & ounce, fluid (fl. oz) \\
\hline liter $(\mathrm{L})$ & 2.113 & pint $(p t)$ \\
\hline liter $(\mathrm{L})$ & 1.057 & quart (qt) \\
\hline liter $(\mathrm{L})$ & 0.2642 & gallon (gal) \\
\hline liter $(\mathrm{L})$ & 61.02 & cubic inch $\left(\mathrm{in}^{3}\right)$ \\
\hline \multicolumn{3}{|c|}{ Mass } \\
\hline $\operatorname{gram}(\mathrm{g})$ & 0.03527 & ounce, avoirdupois (oz) \\
\hline
\end{tabular}

Temperature in degrees Celsius $\left({ }^{\circ} \mathrm{C}\right)$ may be converted to degrees Fahrenheit $\left({ }^{\circ} \mathrm{F}\right)$ as follows: ${ }^{\circ} \mathrm{F}=\left(1.8 \mathrm{x}^{\circ} \mathrm{C}\right)+32$. 


\section{Datum}

Horizontal coordinate information is referenced to the North American Datum of 1983 (NAD 83).

\section{Abbreviations and Acronyms}

\begin{tabular}{ll}
\hline \multicolumn{1}{c}{ Abbreviations } & \multicolumn{1}{c}{ Meaning } \\
\hline CPUE & catch per unit effort \\
DO & dissolved oxygen \\
PIT & passive integrated transponder \\
SD & standard deviation \\
SL & standard length \\
TNC & The Nature Conservancy \\
USGS & U.S. Geological Survey \\
\hline
\end{tabular}


This page left intentionally blank 


\title{
Temporal and Spatial Distribution of Endangered Juvenile Lost River and Shortnose Suckers in Relation to Environmental Variables in Upper Klamath Lake, Oregon: 2009 Annual Data Summary
}

\author{
By Jared L. Bottcher and Summer M. Burdick
}

\section{Executive Summary}

Lost River sucker (Deltistes luxatus) and shortnose sucker (Chasmistes brevirostris) were listed as endangered in 1988 for a variety of reasons including apparent recruitment failure. Upper Klamath Lake, Oregon, and its tributaries are considered the most critical remaining habitat for these two species. Age-0 suckers are often abundant in Upper Klamath Lake throughout the summer months, but catches decline dramatically between late August and early September each year. Similar declines of age-1 suckers between spring and late summer also occur annually. These rapid declines in catch rates and a lack of substantial recruitment into adult sucker populations in recent years suggests sucker populations experience high mortality between their first summer and first spawn.

Summer age-0 sucker habitat use and distribution have been studied extensively, but many uncertainties remain about age- 1 and older juvenile habitat use, distribution, and movement patterns within Upper Klamath Lake. This study was designed to examine seasonal changes in distribution of age-1 suckers in Upper Klamath Lake as they relate to depth and water quality. The results of our third annual spring and summer sampling effort are presented in this report.

Catch data collected in 2009 indicate seasonal changes in age-1 and older juvenile sucker habitat use coincident with changes in water quality. Although age-1 sucker catch rates were again concentrated along the western shore in June and early July, as they were in 2007 and 2008, very few age-1 suckers were captured in Eagle Ridge Trench in 2009-a deepwater area along the western shore extending from Howard Bay to Eagle Ridge Point. Instead, suckers in 2009 were concentrated in the relatively shallow bays along the western shore. Nevertheless, as dissolved-oxygen concentrations decreased in mid-July below sublethal thresholds around the Eagle Ridge Trench, age-1 suckers apparently moved away from the western shore, and subsequently were captured in main lake areas and the eastern shore. Age-1 suckers were noticeably absent from the tributaries of Upper Klamath Lake during periods of chronically low dissolved-oxygen concentrations in the lake, refuting a previously untested hypothesis that tributaries were important age-1 sucker refuge habitats. In addition, declines in overall catch rates for age-1 suckers in August and September, despite intensive sampling, indicates that the apparent declines in abundance may be due to increased mortality and not due to sampling the wrong environments or poor detection probability. 
The remote detection of an age-1 juvenile sucker tagged in Short Creek and subsequently recaptured in the Link River array, more than 30 kilometers away, indicates the capacity of juvenile suckers to migrate relatively long distances. This knowledge, coupled with other remotely detected suckers in the Williamson River, indicates that juvenile sucker movement in Upper Klamath Lake may be common. In order to better quantify movement and potentially survival, future research should focus on tagging more juvenile suckers and taking advantage of the significant passive integrated transponder tag infrastructure throughout Upper Klamath Lake and its tributaries.

In this data summary, we also describe the distribution of age- 0 suckers in Upper Klamath Lake and its tributaries. These data corroborate findings from 2007 and 2008, which describe age- 0 sucker habitat as shallow relative to depths available in Upper Klamath Lake. Similar to age-1 suckers, age-0 sucker abundances also appeared to decline in late summer, despite continued sampling throughout Upper Klamath Lake and its tributaries.

In addition to low dissolved-oxygen concentrations, increased opercle deformity and anchor worm (Lernaea spp.) infection rates, as well as increased abundances of fathead minnows and other piscivorous non-native fish, may provide potential insight into the causes of juvenile sucker rarity. Opercle deformity rates for age-0 suckers were relatively high for the third consecutive year and considerably higher than deformity rates for age-1 and older juveniles. Our brief description of the distribution and abundance of all other fish species caught provides a context in which to assess potential threats posed by non-native piscivores and the rarity of juvenile suckers within the fish community of Upper Klamath Lake.

\section{Project Introduction and Background}

Rapid declines in catch rates for juvenile endangered Lost River sucker (Deltistes luxatus) and shortnose sucker (Chasmistes brevirostris) and a lack of substantial recruitment into adult sucker populations in recent years indicates that these sucker populations experience high mortality between their first summer and first spawn. Low relative catch rates of age-1 compared to age-0 Lost River and shortnose suckers in Upper Klamath Lake, Oregon, may be due to sampling the wrong environments, poor detection probability, the true rarity of this age class, or a combination of these. Dramatic declines in age-0 catch rates between late August and early September each year combined with extremely low catches of age-1 or older suckers in Upper Klamath Lake, Oregon (Hendrixson and others, 2007; Terwilliger and others, 2008) indicate that these species experience unusually high mortality within their first year of life (National Research Council, 2004). This high apparent mortality may be exacerbated by a lack of optimal over-wintering habitat, diminishing rearing habitat, declining summer water quality, or a combination of these. The causes and rates of mortality cannot be adequately assessed, however, without first examining age-dependent catchability and seasonal dynamics in the distribution and habitat use of age- 0 and age- 1 suckers. This is because most methods of assessing mortality depend on the assumptions that all age classes of fish are equally likely to be captured and that a representative sample of individuals from a homogeneously distributed population can be obtained (Hilborn and Walters, 1992). 
One way to examine the value of lake environments as over-wintering habitat is to examine the spatial distribution of post-winter catch rates. Lake environments producing high catch rates of surviving juvenile suckers are assumed to provide better winter habitat. A limited amount of available data indicates post wintering (spring) and early summer distributions of juvenile suckers are concentrated in tributary mouths and near springs. Between April 21 and May 11, 1992, Markle and Simon (1993) caught a relatively high number of age-1 and older subadult suckers (76) in overnight trap nets set in tributaries at the northern end of Upper Klamath Lake. However, they caught few in trap nets set off-shore during the same time period (4) or in off-shore otter trawls conducted each spring since 1996 (fewer than 20 individuals between 1996 and 2006; Simon and others, 2000a, 2000b; Simon and Markle, 2001, 2002, 2006; Terwilliger and others, 2008). U.S. Geological Survey (USGS) employees also caught age-1 suckers near the mouth of the Williamson River and at the springs along the eastern shore in early July between 2004 and 2006 (Burdick and others, 2008a; Hendrixson and others, 2007). Age-1 and older suckers may be selecting springs and tributaries because of their unique water chemistry, warmer winter temperatures, winter productivity, or cooler summer temperatures, but none of these hypotheses have been tested.

Although summer age- 0 sucker habitat use and distribution is fairly well understood in Upper Klamath Lake (VanderKooi and Buelow, 2003; Terwilliger and others, 2004; VanderKooi and others, 2006; Hendrixson and others, 2007; Burdick and others, 2008a, 2008b), almost no information exists on the habitat use and distribution of age-1 suckers. Age-0 suckers use nearshore and off-shore lake environments with and without emergent vegetation (Hendrixson and others, 2007). They also have been captured over a variety of substrates including mud and sand (Buettner and Scoppettone, 1990; Hendrixson and others, 2007) as well as cobble and gravel (Terwilliger and others, 2004; Hendrixson and others, 2007). Between 2001 and 2006, age-1 and older juvenile suckers were sporadically caught in both open water and environments dominated by Schoenoplectus acutus (VanderKooi and Buelow, 2003; VanderKooi and others, 2006; Hendrixson and others, 2007). Catch rates between 2001 and 2006 tended to be slightly greater within $200 \mathrm{~m}$ of shore than in nets set 400 or $600 \mathrm{~m}$ from shore (U.S. Geological Survey, unpub. data, 2001-06). Near-shore sampling from 2004 to 2006 indicated that age-1 and older juvenile suckers were approximately equally dispersed in the northern (56 percent) and southern (44 percent) ends of Upper Klamath Lake (U.S. Geological Survey, unpub. data, 2004-06). Nearshore to off-shore trap net transect surveys at five locations along the eastern shore of Upper Klamath Lake between 2002 and 2006 indicated age-1 suckers were concentrated around Hagelstein Park and the mouth of the Williamson River in early July (VanderKooi and Buelow, 2003; VanderKooi and others, 2006; Hendrixson and others, 2007). However, all these habitat use and distribution trends are based on very small sample sizes and therefore habitat preferences are uncertain.

The effects of water quality on age- 0 and age- 1 sucker distribution are not well understood, but may be a key component in understanding seasonal changes in habitat use. Martin and Saiki (1999) determined that dissolved-oxygen (DO) concentrations are the most critical factor affecting juvenile Lost River sucker survival in Upper Klamath Lake. This may help explain the association between high concentrations of DO and juvenile sucker catch rates (Buettner and Scoppettone, 1990; Terwilliger and others, 2004). Lethal pH levels (approximately 10.5 ) and concentrations of DO (approximately 1.1-2.1 mg/L) for juvenile Lost River and shortnose suckers (Saiki and others, 1999) occur locally in areas of Upper Klamath Lake almost every year (Terwilliger and others, 2004; Wood and others, 2006) and sublethal levels (DO 
concentrations between 4.0 and $6.0 \mathrm{mg} / \mathrm{L}$ and $\mathrm{pH}$ levels between 9.0 and 9.8) (Loftus, 2001) are common throughout the lake in July and August (Lindenberg and others, 2008). DO concentrations and $\mathrm{pH}$ levels in Upper Klamath Lake are positively correlated as a result of increased photosynthetic activity by massive blooms of the cyanobacterium Aphanizomenon flosaquae (Lindenberg and others, 2008). Therefore, environments with both low $\mathrm{pH}$ and high DO concentrations are not normally available during bloom cycles, forcing juvenile suckers to occupy habitats with one or the other. For example, Burdick and others (2008) reported slightly higher occupancy rates by age- 0 suckers at sites with both high daily mean $\mathrm{pH}$ and $\mathrm{DO}$ concentrations rather than at sites with low or moderate daily mean $\mathrm{pH}$ and high DO concentrations.

Data from 2007 and 2008 indicate that age-1 suckers are most abundant in Upper Klamath Lake in May and June, but as DO concentrations decreased, catch rates are reduced throughout the lake, especially in Eagle Ridge Trench along the western shore of the lake (fig. 1) where DO concentrations are routinely below sublethal stress thresholds (Loftus, 2001; Burdick and VanderKooi, 2010). The sampling protocol used in 2007 and 2008 did not allow us to determine if low summer catch rates were due to high sucker mortality, movement away from sampled environments, or reduced summer detection probabilities. For example, because we did not sample off-shore or tributary sites in August and September of 2007 or 2008, we could not determine if juvenile suckers moved away from sampled areas as DO concentrations decreased. Areas of cool water temperatures and relatively high DO concentrations exist in tributaries to Upper Klamath Lake along the northern and western shores, including Short, Odessa, Fourmile, Recreation, Crystal, and Thomason Creeks, and the Williamson River (fig. 1). Recreation, Crystal, and Fourmile Creeks enter into Pelican Bay (fig. 1), which acts as a refuge for adult Lost River and shortnose suckers as DO concentrations in other parts of the lake decrease to less than $4 \mathrm{mg} / \mathrm{L}$ (Banish and others, 2009). In addition, data from 2007 and 2008 indicate that DO concentrations are greater than sublethal stress thresholds more consistently at mid-lake and eastern shore sites than Eagle Ridge Trench sites (U.S. Geological Survey, 2009). In 2009, we began sampling Upper Klamath Lake tributaries, areas of relatively high DO concentrations and low water temperatures (Banish and others, 2009), as well as off-shore sites throughout spring, summer, and early autumn to determine if juveniles use these areas as DO concentrations decrease in Eagle Ridge Trench.

Results from 2007 (Burdick and others, 2009) indicated that age-0 suckers were most likely to use shallow (1.0-3.0 m) water widely available in Upper Klamath Lake throughout the summer although age-1 suckers were most likely to use deep (4.0-5.0 m) water environments in the summer, which are diminished at lower lake-surface elevations. Similar results were found in 2008 when the highest catch rates for age-0 suckers occurred in less than $1 \mathrm{~m}$ of water and the highest catch rates for age-1 suckers occurred in 6.0-7.0 m of water (Burdick and VanderKooi, 2010). This depth selection for age-1 suckers is similar to that of adult suckers, which are known to concentrate at water depths greater than $2.8 \mathrm{~m}$ (Banish and others, 2009).

In 2009, we continued research focused on age-1 and older juvenile sucker habitat use and distribution begun in 2007 and continued research on seasonal dynamics in habitat use by age- 0 suckers begun in 2001 . Continued sampling in 2009 allowed us to track the relatively strong 2006 cohort into their third year of life and examine changes in habitat use as this yearclass ages. Our specific project objectives included: 
Objective 1: Qualitatively examine spring (early May to mid-June), mid-summer (mid-June to mid-August) and late summer (mid-August to early September) spatial distribution of age- 0 , age-1, and older juvenile shortnose and Lost River suckers in Upper Klamath Lake, Oregon, and its tributaries.

Objective 2: Quantitatively estimate detection and habitat use probabilities in Upper Klamath Lake, Oregon, across a range of available depths and habitats for age-0, age1 , and older juvenile shortnose and Lost River suckers.

Objective 3: Examine co-occurrence patterns among sucker and non-sucker species in Upper Klamath Lake, Oregon.

Objective 4: Qualitatively examine the effects of summer water quality on habitat use by age- 0 , age- 1 , and older juvenile shortnose and Lost River suckers.

We set both annual and long-term goals for reporting our results and will produce annual data summaries, as well as comprehensive reports deliverable every 3 years. Annual data summaries, like this one, are peer reviewed open-file reports intended to make data quickly available to our partners and other resource management agencies. Whereas, comprehensive reports will be peer reviewed documents that contain analysis and interpretation of these data.

Differential detection of a species among environments or age classes, often unaccounted for in fisheries research, can lead to biased conclusions about habitat use (MacKenzie, 2005; MacKenzie and others, 2006) or mortality rates. For example, studies that assessed capture efficiency for amphibians and stream-dwelling salmonids determined that gear bias varied among sampling sites and sampling occasions and was dependent on environmental variables (Bailey and others, 2004; Peterson and others, 2004; Weir and others, 2005). The probability of detecting age- 0 suckers in fyke nets set near-shore in less than $3.0 \mathrm{~m}$ of water is negatively correlated with depth and positively associated with catch rates in mid to late summer (Burdick and others, 2008b). Failing to account for these variations in detection may cause erroneously low estimates of habitat use in early summer and deeper water. When catch per unit effort approaches are used to assess habitat use, schooling behavior also may cause imprecise or biased estimates. Catch per unit effort within identical habitats can range dramatically when fish school. This variability will result in imprecise estimates of habitat use. High variability in catch rates due to schooling combined with small sample sizes also may result in biased estimates.

Our 2009 sampling protocol was designed to quantitatively estimate detection probability, distribution, and habitat use of age- 0 and age- 1 suckers throughout Upper Klamath Lake and its tributaries during the sampling season. Our approach will eventually allow us to evaluate the importance of water depth, water quality, and season in relation to habitat use and detection probability of age- 0 and age- 1 suckers. The information we present in this data summary and future reports regarding the distribution and habitat use for age- 0 and age- 1 suckers will help improve sampling design for future research and assist in management of water resources, endangered species, and restoration efforts. 


\section{Study Area}

Our study area is located in the Upper Klamath Basin of southern Oregon and northern California. The project area is located entirely within Upper Klamath Lake, the largest lake in the basin (fig. 1). Upper Klamath Lake, which covers approximately $271 \mathrm{~km}^{2}$ (67,000 acres) at full pool, is uniformly shallow, averaging less than $2.1 \mathrm{~m}$ in depth at mean summer lake-surface elevation except in a trench along the western shore, which has depths between 6.4 and $9.5 \mathrm{~m}$ (National Research Council, 2004). Before the construction of the Link River Dam in 1921, the surface elevation of Upper Klamath Lake only varied by about $1 \mathrm{~m}$ over the entire year (National Research Council, 2004). The construction of the dam allowed surface elevation to be drawn down by an additional $1 \mathrm{~m}$ (National Research Council, 2004).

Poor water quality in Upper Klamath Lake is associated with massive blooms and subsequent die-offs of the blue-green cyanobacterium $A$. flos-aquae. Spatial patterns in water quality change with weather conditions, including wind and water temperature (Wood and others, 2008). During the spring, DO concentrations generally are suitable for juvenile suckers throughout Upper Klamath Lake (Lindenberg and others, 2008). As air and water temperatures increase in the summer, A. flos-aquae produces massive blooms (Lindenberg and others, 2008). Then, between mid-July and early August each year, chlorophyll $a$ concentrations rapidly decrease, indicating a massive algal die-off event. The large-scale cell senescence that occurs during such events is associated with rapid decreases in daily median $\mathrm{pH}$ and $\mathrm{DO}$ concentrations (Lindenberg and others, 2008). This phenomenon, which is referred to locally as the "bloomcrash", usually occurs first and is the most severe in Eagle Ridge Trench along the western shore of Upper Klamath Lake (fig. 1) (Lindenberg and others, 2008). Dissolved oxygen concentrations are lowest in the deepest part of the lake where they can be less than $4 \mathrm{mg} / \mathrm{L}$ for several days (Lindenberg and others, 2008).

The tributaries and spring areas along the northwestern shore of Upper Klamath Lake, including Pelican Bay (fig. 1) are recharged by groundwater and remain relatively free of algal blooms. This area provides refuge for adult suckers during periods of low DO concentrations in Upper Klamath Lake (Mulligan and Mulligan, 2007; Banish and others, 2009). In contrast to Upper Klamath Lake, the tributaries and springs that feed Pelican Bay, including Crystal, Fourmile, and Recreation Creeks, provide cooler, well oxygenated water, throughout the hottest summer months (Banish and others, 2009). These areas, including Harriman Springs, historically provided spawning habitat for Lost River suckers (National Research Council, 2004) and still provide refuge to adult suckers during periods of elevated water temperature and consistently low DO concentrations (Banish and others, 2009). These creeks are relatively short (Crystal Creek is $6.0 \mathrm{~km}$ and Recreation Creek is $3.7 \mathrm{~km}$ in length) and typically are heavily vegetated with wocus (Nuphar spp.), tules (Schoenoplectus actus), and willows (Salix spp.). Substrates vary by stream, but typically consist of fines in Crystal, Recreation, and Fourmile Creeks. The area around Harriman Springs, however, provides much larger substrates than the surrounding tributaries (Mulligan and Mulligan, 2007). 


\section{Methods}

\section{Approach}

We used a random stratified sampling design to address objectives one through four, to collect age-1 suckers that could be tagged, to collect fish for a concurrent fish health study, and to examine age- 0 and age- 1 sucker seasonal habitat use in Upper Klamath Lake. We sampled six strata, which included near-shore and off-shore strata in each of three areas of Upper Klamath Lake: (1) north and west of Eagle Point and the mouth of the Williamson River (North), (2) south and east of Eagle Point and the mouth of the Williamson River and north of Sesti Tgawaals Point and Hagelstein Park (Central), and (3) south of Hagelstein Park and Sesti Tgawaals Point including Howard Bay (South) (fig. 1). In addition to the six strata within the lake, we sampled sites in several tributaries of the lake, including the Williamson River, and Crystal, Fourmile, Recreation, Short, Odessa, and Thomason Creeks (fig. 1). Sites available for sampling within the lake were conceptualized as 2,500- $\mathrm{m}^{2}$ cells. Available near-shore sites consisted of a concentric $50 \times 50-\mathrm{m}$ rectangular band running along the entire shoreline. Off-shore sites were considered hexagonal cells at least $100 \mathrm{~m}$ from shore. Sites were set at slightly different areas in the tributaries during each sampling occasion, but were always set at a minimum of $100 \mathrm{~m}$ from the mouth. Sampling in Upper Klamath Lake coincided with sampling in and near the Williamson River Delta conducted under agreement 04AA204032 with the Bureau of Reclamation.

We divided the sampling period into three seasons; May 3 through June 20 (spring), June 21 through August 8 (mid-summer), and August 9 through September 17 (late-summer). Most sites sampled in 2009 were sampled in 2008 and 2007 to facilitate interannual comparisons among age- 0 and age- 1 sucker catch rates. To better understand the temporal and spatial variability in catch rates between seasons, the sampling locations visited during the first 7 -week period (spring) were revisited during the mid-summer sampling period and most sites were sampled for a third time during the late-summer period. We were unable to revisit all sites sampled in the spring and mid-summer sampling periods during late-summer due to declining lake-surface elevations. Seasonal sample allocation was designed to capture age- 1 and older juvenile suckers in the spring, the peak of age- 0 sucker abundance in the mid-summer period, and the decline of age- 0 and age- 1 sucker abundance in the late-summer period. We sampled near-shore, off-shore, and tributary sites in all sampling periods and covered a range of water depths available in Upper Klamath Lake. We delineated these time periods based on historical catch data for age-0 and age-1 suckers (VanderKooi and others, 2006; Hendrixson and others, 2007; Burdick and others, 2008a, 2009); a technique that will allow us to address objective one.

We set three replicate nets at each site during each sampling season to meet the requirements of occupancy models in estimating detection and unbiased habitat use probabilities (objective 2). When three nets were set at one site, the mouth openings were arranged to be about 120 degrees to each other to avoid interference among nets. 


\section{Sample Collection}

Juvenile fish were sampled with rectangular nets with mouth dimensions of $0.61 \times 0.91$ $\mathrm{m}$, a $10-\mathrm{m}$ lead, and three internal fykes. These nets were fitted with $6.4 \mathrm{~mm}$ green nylon netting. In an attempt to capture and tag age- 2 and older juvenile suckers, large fyke nets, with mouth dimensions of $1.22 \times 1.83 \mathrm{~m}$, three internal fykes, and a $15-\mathrm{m}$ lead, were set at two randomly selected sites each day. Nets were set between 1059 and 1745 hours each afternoon and pulled the next day between 0747 and 1555 hours, for a target soak time of 20 hours. Net set and pull times and the depth at both the end of the lead line and at the net mouth were recorded for each net. Lead and mouth depths for all nets at each site were averaged for this data summary. At each site, we probed the bottom of the lake with a PVC pipe or a weighted depth rope, and made an educated guess about substrate composition. The percentage of the entire site covered with vegetation and the portion of plants in each genus within a random $1 \mathrm{~m}^{2}$ sample also were recorded.

Captured fish were identified to species or lowest practical taxonomic group and counted. For all suckers, standard length (SL) was measured and the presence of deformities and macroparasites were noted. When catches exceeded $3 \mathrm{~kg}$, a subsample was taken for all species except juvenile suckers. Subsamples were taken by weighing the entire sample and removing approximately 30 percent of the weight for standard measurement and enumeration. The remaining 70 percent of the catch was examined for the presence and absence of each species by four size bins (tiny < $40 \mathrm{~mm}$ SL; small 40-100 mm SL; medium 100-200 mm SL; and larger than $200 \mathrm{~mm} \mathrm{SL}$ ) and all suckers were measured and removed from the sample. The total number of each species except suckers in the total catch was estimated by extrapolation using the ratio of subsample weight to total weight. Subsample species composition was assumed representative of total catch. Catch per unit effort (CPUE) was calculated as fish per net rather than fish per hour for each non-sucker species because there was not a relation between the number of fish captured and the length of time that nets were in the water.

As a preliminary step in studying movement patterns in relation to environmental variables, suckers $70 \mathrm{~mm}$ SL or longer collected during spring sampling were injected with a full duplex, $12.45 \times 2.02 \mathrm{~mm}, 0.106 \mathrm{~g}$ in air, $134.2 \mathrm{kHz}$, cylindrical passive integrated transponder (PIT) tag. Juvenile suckers that were $70 \mathrm{~mm}$ SL or greater, and were collected in water less than $19{ }^{\circ} \mathrm{C}$ and before July 1 were tagged. Prior to tagging, suckers were scanned for the presence of a tag and anesthetized in a 0.02 to $0.03 \mathrm{mg} / \mathrm{L}$ solution of MS-222, which was prepared with lake water. All suckers were allowed to remain in the solution until they did not respond to probing. All taggers were trained using preserved specimens prior to tagging live fish. Between each injection, needles were sterilized with Nolvasan ${ }^{\circledR}$ disinfectant. Wounds were not closed with sutures and no antibiotics were administered. Tagged suckers were allowed to recover in a bucket of lake water prior to release at the site of capture.

Approximately one out of three captured suckers $70 \mathrm{~mm}$ SL or less and one out of ten suckers 71 to $145 \mathrm{~mm}$ SL were sacrificed and preserved in 95 percent denatured ethanol for identification to species. Sacrificed suckers were weighed upon returning to the laboratory. We identified juvenile suckers to species in the laboratory with a method developed by Markle and others (2005) using a combination of techniques including vertebrae enumeration, lip morphology, and gill raker counts. The estimated number of each sucker species in a catch was obtained by multiplying the species proportion in the subsample of sacrificed fish by the total number of juvenile suckers caught in the sample. 


\section{Water-Quality Data}

Water-quality data were collected separately by the USGS Oregon Water Science Center for a concurrent lake water-quality study. These data, which are publicly available through an agency web site (U.S. Geological Survey, 2009), were collected at 14 sites throughout Upper Klamath Lake in 2009. At each site, YSI (model 600XLM or model 6920) continuous waterquality monitors were deployed $1 \mathrm{~m}$ off the lake bottom. Monitors measured DO concentration, $\mathrm{pH}$, specific conductance, and temperature once hourly between early May and early October 2009. In this report, we give an abbreviated summary of temperature and DO concentration data collected at three sites in order to put the spatial-temporal distributions of juvenile suckers in context (objective 4). Data from three water-quality monitoring stations were examined for this report. The Eagle Point station (USGS site EPT-L, 422559121574400) is representative of conditions in Eagle Ridge Trench. The south shore site (USGS site SSR, 421410121492000) is representative of conditions south of Buck Island. The mid-north station (UGSS site MDN-L, 422622122004000) is representative of conditions north of Ball Bay and Shoalwater Bay, east of Howard Bay and Eagle Ridge Trench, and north of Buck Island (fig. 1; U.S. Geological Survey, 2009).

\section{Summarizing and Reporting Data}

Juvenile sucker catch data were summarized to describe spatial-temporal patterns in distribution and relative abundance, species composition, and age and length structure in the sampled population. We classified suckers as age-0, age-1, or older based on weekly length frequency plots. We calculated age-specific catch rates to describe the magnitude of catches and naïve occupancy to describe the extent of spatial distribution. Catch rates were calculated as fish per net rather than fish per hour because we were not able to determine any relation between the number of fish and the number of hours a net was set. Naïve occupancy was calculated as the percentage of sites at which we caught at least one sucker in a category of interest. This value is known as the naïve occupancy rate because it has not been adjusted for a reduced probability of detection.

We summarized the frequency of parasites and deformities, calculated the relative weight for each sacrificed age- 0 sucker that was weighed, and described the size of juvenile suckers in each age class to describe general condition of juvenile suckers in our catches. Relative weight $\left(W_{r}\right)$ was calculated as the weight for each age-0 sucker divided by the predicted weight, based on species specific length-weight relationships established for age-0 suckers caught in 2006 (Burdick and others, 2008a), and multiplied by 100 (Anderson and Neumann, 1996). Relative weight values of 100 indicate suckers with similar length weight ratios as those collected in 2006, whereas values less than 100 indicate emaciation and values greater than 100 indicate that fish were rotund relative to the typical sucker caught in 2006 (Anderson and Neumann, 1996). 
Catch data for other species was summarized to describe the timing and magnitude of catches for individual species, and the overall diversity and structure of communities. To assist in describing community structure, we calculated species richness and the Shannon-Wiener index of diversity (McCune and Grace, 2002) for each week and in each major stratum. The ShannonWiener index $\left(\mathrm{H}^{\prime}\right)$ is defined as

$$
H^{\prime}=\sum_{i=1}^{s}\left(p_{i}\right)\left(\log _{e} p_{i}\right)
$$

where $s=$ the number of species, and $p_{i}=$ proportion of the total sample represented by the ${ }_{i}$ th species. We grouped all rare species, which comprised 10 of the 13 non-sucker species found within Upper Klamath Lake, into one category when determining catch per unit effort. In 2009, these 10 species combined accounted for less than 6.5 percent of the total catch (range 3.3-6.5 percent) in each stratum. We standardized each Shannon-Wiener weekly index value by the highest value found within each stratum across the entire sampling season, resulting in ShannonWiener index values bounded by one and zero. The Shannon-Wiener index is a method of describing the richness and evenness in a given community. A high standardized ShannonWiener index value (near one) indicates more equal representation of species in a community or sample, relative to a low standardized Shannon-Wiener index value (near zero).

\section{Results of Sample Collection and Data Summary}

\section{Sampling Effort}

During 20 weeks of sampling in Upper Klamath Lake and a pilot sampling day on April 16 , we set 1,289 trap nets at 382 sites for a total of 27,534 hours of soak time. The duration of trap net samples ranged from 13.8 to 26.4 hours and averaged $21.4 \pm 3.6$ hours (mean $\pm \mathrm{SD}$ ). Four nets failed during the spring sampling season (one in the South Near-shore stratum, one in the Central Off-shore stratum, and two in the North Near-shore stratum), and one failed during the mid-summer sampling season (South Off-shore stratum). Catches from failed nets are not included in this data summary. Most sites (58 percent; 90 sites) were visited three times, although 47 sites ( 30 percent) were visited twice, and 18 sites ( 12 percent) were visited only once, resulting in a total of 382 site visits at 155 sites (table 1). We subsampled 90 catches that weighed between 2.8 and $77.0 \mathrm{~kg}$ and averaged $9.1 \pm 11.4 \mathrm{~kg}(\mathrm{mean} \pm \mathrm{SD})$.

During 19 weeks of sampling in the tributaries of Upper Klamath Lake, we set 240 fyke nets at 71 sites for a total of 4,989 hours of soak time. Three nets failed in the tributaries: one each in Crystal Creek, Short Creek, and the Williamson River. The duration of trap net samples ranged from 10.1 to 26.0 hours and averaged $21.1 \pm 1.5$ hours (mean $\pm \mathrm{SD}$ ). We sampled 7 sites in Crystal Creek, 8 sites in Fourmile Creek, 11 sites in Odessa Creek, 6 sites in Recreation Creek, 9 sites in Short Creek, 20 sites in Thomason Creek, and 10 sites in the Williamson River. We subsampled 12 nets set in tributaries including 5 in Crystal Creek and 7 in Thomason Creek, with total weights ranging from 5.4 to $23.5 \mathrm{~kg}$. 


\section{Summary of Water-Quality Conditions}

Seasonal trends in DO concentrations and temperature were similar for the EPT-L and MDN-L water-quality sites, but both were markedly different than temperature and DO trends at site SSR (fig. 2). Temperature at all three sites increased between June 21 and August 2; the temperature was highest at site SSR $\left(28.0^{\circ} \mathrm{C}\right)$ on July 30 . The maximum temperatures were 24.3 ${ }^{\circ} \mathrm{C}$ at site EPT-L and $24.6{ }^{\circ} \mathrm{C}$ at site MDN-L. Diel variation in water temperature was lowest at site EPT-L, slightly higher at site MDN-L, and highest at site SSR (fig. 2). With the exception of a few days in early July at site EPT-L, DO concentrations at sites EPT-L and MDN-L were greater than $4.00 \mathrm{mg} / \mathrm{L}$ until July 15 . At site EPT-L, daily median concentrations were less than $4.00 \mathrm{mg} / \mathrm{L}$ from July 15 to August 1 . A similar trend occurred at site MDN-L, where daily median DO concentrations were less than $4.00 \mathrm{mg} / \mathrm{L}$ between July 16 and July 31 . However, as water temperatures declined at all three sites beginning in early August, median DO concentrations increased and were greater than $4.00 \mathrm{mg} / \mathrm{L}$ at sites MDN-L and SSR until September 16. Although DO concentrations at site EPT-L increased after August 1 and daily median values were greater than $4.00 \mathrm{mg} / \mathrm{L}$ until August 18, daily median DO concentrations fluctuated between 0.03 and $8.59 \mathrm{mg} / \mathrm{L}$ until September 17 . Median daily DO concentrations at site EPT-L were less than $4.00 \mathrm{mg} / \mathrm{L}$ on 63 days, less than $2.00 \mathrm{mg} / \mathrm{L}$ on 28 days, and less than $0.50 \mathrm{mg} / \mathrm{L}$ on 10 days. In contrast, daily median DO concentrations at site MDN-L only decreased to less than $4.00 \mathrm{mg} / \mathrm{L}$ on 25 days, less than $2.00 \mathrm{mg} / \mathrm{L}$ on 5 days, and did not decrease to less than $0.50 \mathrm{mg} / \mathrm{L}$. At site SSR, individual hourly DO concentrations decreased to less than $4.00 \mathrm{mg} / \mathrm{L}$ on only two occasions and median daily DO values never decreased to less than 4.00 $\mathrm{mg} / \mathrm{L}$.

\section{Age and Species Composition of Juvenile Suckers}

We captured 253 juvenile suckers in Upper Klamath Lake, Oregon, between April 16 and September 16. Based on weekly length frequency distributions, we estimate that about 62 percent of these suckers were age-0 (156 suckers), 36 percent were age-1 (90 suckers), and 2 percent were age-2 (7 suckers) (fig. 3). In addition, we collected 12 older juvenile and adult suckers during the same time period. We sacrificed 91 age- 0 suckers and 13 age- 1 suckers for identification to species, histology, or collection of tissues for a related on-going fish health study. Most sacrificed age- 0 suckers were identified as Lost River suckers (43 percent), and shortnose suckers comprised 31 percent of the sacrificed age- 0 suckers. We identified one sacrificed age- 0 sucker as a Klamath largescale sucker (1 percent). The remainder of the catch was identified as having intermediate characteristics of Lost River, shortnose, and Klamath largescale suckers (25 percent). One of the 13 sacrificed age- 1 suckers ( 8 percent) was identified as a Lost River sucker, 9 were identified as shortnose suckers (69 percent), and 3 (23 percent) were identified as having intermediate characteristics of Lost River, shortnose, or Klamath largescale suckers. 
We collected 39 suckers from the tributaries of Upper Klamath Lake in 2009. Of those, 21 percent ( 8 suckers) were age- 0,72 percent ( 28 suckers) were age-1, and 7 percent ( 3 suckers) were age- 2 . We sacrificed three age- 0 suckers and one age- 1 sucker from tributaries. The sacrificed age-0 suckers were collected from Short Creek and the Williamson River and consisted of one Lost River sucker, one shortnose sucker, and one identified as having intermediate characteristics of Lost River, shortnose, or Klamath largescale suckers. The one sacrificed age-1 sucker was collected in the Williamson River and was identified as a shortnose sucker.

\section{Spatial-Temporal Patterns in Age-1 and Age-2 Sucker Catches}

Mean $( \pm \mathrm{SD})$ weekly age-1 sucker catch rates (suckers per net) were variable and ranged from a high of $0.59 \pm 2.00$ during the week of June 12 to a low of 0.00 during 6 separate weeks between May 3 and September 13 (fig. 4). Age-1 sucker catch rates generally increased between May 17 and July 12, decreased the week of July 19, and remained low for the remainder of the field season. The percentage of sites sampled each week at which at least one age-1 sucker was detected ranged from 0 to 27 (fig. 4), but the median weekly detection rate was only 8 percent. During the 20-week sampling season in Upper Klamath Lake, we did not catch age-1 suckers during 6 weeks and we did not catch age- 2 suckers during 15 weeks. Of the seven age- 2 suckers collected from May 4 to September 16, five were captured between August 2 and August 22, a time during which age-1 catch rates were low.

Age-1 suckers were collected in every stratum from May 4 to September 16, 2009. Irrespective of time, age-1 sucker catch rates were 10 times greater in each near-shore strata than in their corresponding off-shore strata, with the highest catch rates occurring in the Central Nearshore stratum ( 0.22 suckers per net; table 2$)$. We collected seven age- 2 suckers between May 4 and September 16 in five of the six strata, preventing the detection of spatial-temporal trends. Mean ( \pm SD) age-1 sucker weekly catch rates (suckers per net) peaked near-shore during the week of July 12 at $1.72 \pm 3.30$ and off-shore during the week of July 19 at $0.11 \pm 0.24$ (fig. 5). After peaks in both near-shore and off-shore strata in mid-July, catch rates declined and remained low for the remainder of the field season (fig. 5). Age-1 sucker catch rates were consistently higher in tributaries than in near-shore and off-shore strata from May 17 to June 7, when means ( \pm SD) ranged from $0.33 \pm 0.00$ to $0.47 \pm 0.45$. Mean $( \pm$ SD) catch rates in the tributaries peaked during the week of July 12 at $0.67 \pm 0.00$ suckers per net, but like the nearshore and off-shore strata, catch rates declined thereafter and were zero or near-zero from July 19 to September 16 (fig. 5).

Age-1 sucker distribution shifted seasonally between near shore and off shore and the western and eastern shores. In the spring, from May 3 to June 20, all nine sites where age-1 suckers were collected were in near-shore habitat in the south, central, and north parts of the lake. During the mid-summer sampling period, age-1 suckers were again concentrated in nearshore strata ( 83 percent). Of the 25 sites that age- 1 suckers were collected at during the midsummer period, 11 were in the south (44 percent), 8 were in the central (32 percent), and 6 (24 percent) were in the northern area of the lake (fig. 6). Between June 14 and July 11, 88 percent of sites with at least one age-1 sucker caught were located along the western side of the lake, including in Howard Bay. From July 12 to August 8, however, catches primarily occurred along the eastern shore and off shore. In the late-summer sampling period (August 9-September 17), age-1 suckers were collected only at three sites: two in the Central Near-shore stratum and one in the North Off-shore stratum (fig. 6). 
Age-1 and age-2 sucker catches occurred at water depths between 1.1 and $10.5 \mathrm{~m}$, but the median depth of sites at which these fish were caught $(3.7 \mathrm{~m})$ was only slightly less than the median depth at all sites sampled $(3.9 \mathrm{~m})$. The relatively small sample size for both age- 1 and age-2 suckers and small depth differences between seasons, however, limited our ability to infer any sort of differential depth distribution among seasons (fig. 7).

In general, age-1 and age-2 sucker catch rates in tributaries followed the same pattern exhibited in the main lake; catches were relatively high early in the season, declined around midJuly, and remained low for the remainder of the field season. We collected 28 age- 1 suckers and 3 age-2 suckers between May 4 and September 16, 2009 in the tributaries. The vast majority (96 percent) of age-1 sucker catches occurred in tributaries from May 10 to June 12, 2009, a time when age-1 catches throughout Upper Klamath Lake were relatively low. Catch rates peaked during the week of May 17 in Short and Thomason Creeks. Catch rates also were relatively high in these creeks during the week of June 7. Most age-1 suckers were collected in Short Creek (11 suckers) and Thomason Creek (6 suckers). Other tributaries produced fewer age-1 suckers, including the Williamson River (5 suckers), Crystal Creek (4 suckers), and Odessa Creek (2 suckers). We did not collect any age-1 or age-2 suckers in Fourmile Creek. There was no pattern in age-2 sucker catches; one was collected in Short Creek in mid-May, one was collected in Odessa Creek in late July, and one was collected in Recreation Creek in early September.

\section{PIT Tagged Juvenile Suckers}

We PIT tagged 37 age-1 and older juvenile suckers (70-300 mm SL) captured in Upper Klamath Lake and its tributaries between May 13 and June 24. Of these, 20 were captured in the lake and 17 in tributaries. Most suckers collected and tagged in tributaries were captured in Short Creek (8 suckers). No juvenile suckers tagged in Upper Klamath Lake or its tributaries were physically recaptured with a PIT tag during this study. One age-1 sucker collected and tagged in Short Creek on June 4, was subsequently detected moving up the Link River fish ladder into Upper Klamath Lake on August 5 and 6. It took this fish, which was $80 \mathrm{~mm}$ SL when tagged, less than $24 \mathrm{~h}$ to traverse all four arrays of the Link River fish ladder.

\section{Spatial-Temporal Patterns in Age-0 Sucker Catches}

Catch rates for age-0 suckers exhibited a tri-modal distribution across weeks (fig. 8). Age-0 suckers began recruiting to our nets during the week of July 12 between 32 and $49 \mathrm{~mm} \mathrm{SL}$ (fig. 7). The mean weakly catch rates peaked during the week of July 19, which coincided with the first confirmed detection of age-0 shortnose suckers (fig. 8). Age-0 sucker mean weekly catch rates declined steadily thereafter until the week of August 2 before increasing again to a second peak the week of August 9. After August 9, age-0 mean weekly catch rates declined and remained low for the remainder of the field season (September 16) (fig. 8).

The weekly naïve occupancy rate (percentage of nets that caught at least one sucker) ranged from 10 to 57 percent and exhibited a distribution similar to age-0 catch rates (fig. 8). Weekly naïve occupancy rates were relatively low in early July, but increased to 40 percent during the week of July 26. This rate decreased during the week of August 2 before peaking at 57 percent during the week of August 9 (fig. 8). Naïve occupancy rates decreased from August 16 to August 30, and remained low for the remainder of the field season (10-20 percent). 
Age-0 Lost River suckers were captured slightly earlier than shortnose suckers. Age-0 Lost River suckers were first detected in our samples the week of July 12, but age-0 shortnose suckers were not detected until the week of July 19 (fig. 8). Mean weekly catches were higher for Lost River suckers than shortnose suckers during the middle and end of July with the highest mean weekly catch rates for Lost River suckers occurring during the weeks of July 19 and July 26. Catch rates for shortnose suckers were highest during the week of August 9. Catches of shortnose suckers also were moderately high during the weeks of August 16 and September 6 (fig. 8).

The distribution of age- 0 sucker catches shifted slightly from near shore to off shore and from south to north as the summer progressed. Age- 0 suckers were first detected during the week of July 12 in all three near-shore strata and the South Off-shore stratum (figs. 9 and 10). Age-0 suckers were first detected in the Central Off-shore stratum 1 week later (July 19) and 2 weeks later (July 26) in the North Off-shore stratum (fig. 9). Catch rates were highest in the South and Central Near-shore strata during the week of July 19, but catch rates and naïve occupancy rates remained relatively low thereafter. Conversely, catch rates in the North Near-shore stratum were relatively low through July before peaking during the weeks of August 9 and August 16. Catch rates remained higher in the North-Near-shore stratum for the remainder of the field season than in the Central and South Near-shore strata (fig. 10). Catch rates and naïve occupancy rates in the off-shore strata primarily were highest in the north, where catches peaked during the weeks of July 26 and August 16. The mean $( \pm$ SD) and median naïve occupancy rate was much higher in all near-shore strata combined $($ mean $=47.5 \pm 31.8$, median $=46.5)$ than in all off-shore strata combined $($ mean $=22.3 \pm 22.1$, median $=25)$.

Age-0 suckers were detected earlier in the Williamson River than in Upper Klamath Lake, but otherwise catch rates were similar in tributaries and the lake itself. The first age-0 sucker was caught in the Williamson River on June 30 and the last age-0 sucker was collected during the last week of tributary sampling (September 6). Age-0 catches were variable among tributaries and seasons, but remained low at all tributary sites. Only two sampling occasions produced more than one age- 0 sucker; one site in Short Creek and one in Odessa Creek. We did not collect age- 0 suckers in 5 of the 11 weeks of tributary sampling between the first and last detection. In addition, we did not collect any age- 0 suckers in Fourmile, Recreation, or Crystal Creeks. Low catch rates limited our ability to analyze spatial or temporal patterns in age-0 sucker tributary use.

Age-0 Lost River and shortnose suckers were most commonly detected in shallow water, but there were some temporal patterns in the depths used by these fish. When combined over all 10 weeks that age- 0 suckers were detected in Upper Klamath Lake, mean catch rates were highest at sites with trap nets set in 1.0-2.0 m of water and lowest at sites with trap nets set in greater than $6.0 \mathrm{~m}$ of water (fig. 11). A similar pattern was revealed after examining speciesspecific catch rates among a range of depths; peak age-0 Lost River and shortnose sucker catch rates occurred in water depths of 1.0-2.0 m, and were lowest at sites greater than $6.0 \mathrm{~m}$ (fig. 11). The median weekly depths for sites at which age-0 suckers were collected were at least $0.9 \mathrm{~m}$ shallower (range 0.9-1.9 m) than the median depths of all sites sampled during the weeks of July 12 to July 26 (fig. 7). The opposite was true during the weeks of August 2 and August 9, when the median weekly depths for sites at which age-0 sucker catches occurred were slightly deeper than the median depths of all sites sampled (fig. 7). The median weekly depths at which age-0 suckers were captured decreased to approximately $0.8 \mathrm{~m}$ less than median sample depths during this same time period. 


\section{Juvenile Sucker Condition}

Deformed opercles were commonly observed on age-0 Lost River and shortnose suckers, but were rarely observed on age- 1 suckers and absent on age- 2 suckers. Regardless of species, 17 percent of age- 0 suckers had at least one deformed opercle and 2 percent exhibited deformities on both opercles. Shortnose suckers exhibited a slightly higher deformity rate than Lost River suckers; 21 percent of shortnose suckers had one deformed opercle, whereas only 13 percent of Lost River suckers had at least one deformed opercle. Forty percent of Lost River suckers with at least one deformed opercle, exhibited deformities on both opercles. Only 2 percent of age-1 suckers had at least one deformed opercle, and only 1 percent had two deformed opercles. The one age-0 Klamath largescale sucker we collected did not have deformed opercles.

Parasitic female anchor worms (Lernaea spp.) occurred on a high percentage of juvenile suckers in Upper Klamath Lake. Eighteen percent of age-0 suckers were parasitized with at least one anchor worm and 32 percent of the parasitized fish had more than one anchor worm attached. Sacrificed Lost River suckers had higher parasitism rates ( 53 percent) than sacrificed shortnose suckers (32 percent). Anchor worm parasitism occurred on 33 percent of age-0 suckers collected in August, compared to only 3 percent collected in July and 9 percent collected in September. Anchor worms were attached to 50 percent ( 45 suckers) of captured age-1 suckers, with 56 percent (25 suckers) having more than one anchor worm (range 1-11). Seventy-nine percent of age-1 suckers collected from Upper Klamath Lake in August had anchor worms, compared to only 26 percent in June and 0 percent in May. Anchor worms were present on 43 percent of captured age- 2 suckers ( 3 suckers). Each age- 2 sucker also had a relatively high number of attached anchor worms (range 9-12).

Juvenile suckers collected in the tributaries experienced similar opercle deformity rates but slightly lower anchor worm infestation than juvenile suckers collected throughout Upper Klamath Lake. Thirteen percent of age- 0 suckers ( 1 sucker) collected from tributaries had one deformed opercle, 4 percent (1 sucker) of age- 1 suckers had one deformed opercle, and age- 2 suckers were free of deformities. The frequency and severity (attached anchor worms per sucker) of anchor worm infestations were similar for age- 0 suckers and slightly less in age- 1 suckers collected from tributaries than suckers collected from Upper Klamath Lake; one out of four age0 suckers collected in tributaries had one anchor worm attached while 32 percent of age-1 suckers were infected with anchor worms (range 1-6). The prevalence of anchor worms on age-1 suckers collected in tributaries was 83 percent in July and August and 26 percent in May and June. The three age- 2 suckers collected in the tributaries had far fewer anchor worms per fish (12) than infected age-2 suckers collected from Upper Klamath Lake (9-12).

Length and weight data indicate that age- 0 suckers grew and were in relatively good condition. When weekly sample sizes were large enough, $(\mathrm{n} \geq 5)$, median standard length (mm) of age- 0 suckers generally increased each week in the north, central, and south strata. Exceptions to this pattern include decreases in weekly median standard length in the north strata between the weeks of August 2 and August 9 and August 16 and August 23 (fig. 12). Only 44 age-0 suckers (28 Lost River suckers and 16 shortnose suckers) were weighed prior to dissection, and therefore suitable for inclusion in the relative weight assessment. The mean $( \pm \mathrm{SD})$ relative weight $\left(W_{r}\right)$ for age-0 Lost River suckers caught in Upper Klamath Lake in 2009 was $92.9 \pm 8.9$, indicating these fish were slightly lighter, given their length, than the same sized fish caught in near-shore habitat in 2006. Similarly, the mean $( \pm \mathrm{SD})$ relative weight $\left(W_{r}\right)$ for age-0 shortnose suckers caught in Upper Klamath Lake in 2009 was $98.1 \pm 10.0$, indicating these fish also were slightly lighter than age-0 shortnose suckers collected in near-shore habitat in 2006. 


\section{Summary of Bycatch}

We captured a total of 13 non-sucker fish species in our trap net sampling between May 4 and September 16. Our catches were dominated by tui chub (Gila bicolor), blue chub (Gila coerulea), and fathead minnow (Pimephales promelas; fig. 13). Other species collected include yellow perch (Perca flavescens), Klamath Lake sculpin (Cottus princeps), Upper Klamath marbled sculpin (Cottus klamathensis klamathensis), brown bullhead, and lamprey (Lampetra spp.). Pumpkinseed (Lepomis gibbosus), slender sculpin (Cottus tenuis), largemouth bass (Micropterus salmoides), redband trout (Oncorhynchus newberii), and speckled dace (Rhinichthys osculus) were rare in our catches (fig. 13). Together, these 10 species accounted for less than 6.5 percent of the total catch (range 3.3-4.6 percent)

Species composition generally was similar among all parts of the lake with some minor variations. Fathead minnows were common in all strata, but were especially prevalent in late summer from August 9 to September 16. Fathead minnow catch rates were highest in the north strata during the weeks of September 6 and 13 (fig. 13). Blue and tui chub catch rates remained relatively constant through time and across strata. Catch rates for all other fish species were highest in the south strata during the week of July 26, the central strata during the week of August 23, and the north strata during the week of August 16.

Species richness was very similar between strata and among weeks, and ranged from a low of 5 during the week of May 3 in the central strata to a high of 10 during several weeks in the central and north strata. Median and mean species richness were very similar across weeks and among strata. The standardized Shannon-Wiener diversity index values were highest during the weeks of May 10 in the south, July 26 in the central strata, and May 17 in the north strata, all of which occurred during periods of relatively low CPUE. The Shannon-Wiener diversity index values were lowest during weeks where catches were dominated by one species, typically fathead minnow or tui chub. In the south strata, weeks with exceptionally low diversity index values include June 28, August 16, and August 23 (range 0.32-0.49). Shannon-Wiener values were low in the central strata during the weeks of June 28 and July 5 (range 0.55-0.64). Lastly, catches in the north strata were the least diverse during the weeks of September 6 and September 13 (range 0.35-0.48).

\section{Discussion}

\section{Distribution and Movement of Age-1 and Older Juvenile Suckers}

Throughout the 2009 sampling season, age-1 sucker catch rates averaged 0.10 suckers per net, which is slightly higher than in 2008 (0.04 suckers per net). The mean CPUE, however, is well below what was reported in 2007 ( 0.27 suckers per net) when the relatively strong 2006 cohort was present in catches. Despite increased sampling effort in tributaries and off-shore areas in 2009, age-1 catch rates remained low. This supports past conclusions that age- 1 sucker abundances are low throughout Upper Klamath Lake.

Age-1 sucker catch rates were consistently greater, although not statistically tested, in near-shore habitat than off-shore habitat throughout the spring, summer, and early autumn. Offshore habitat was only sampled during a 5-week period in 2008 so did not allow for consistent temporal comparisons between near-shore and off-shore habitat use. In 2009, however, catch rates were consistently higher in near-shore than off-shore environments throughout the entire sampling season despite extensive off-shore sampling. The differences were considerable with 
catch rates in near-shore sites an order of magnitude greater than those in corresponding offshore sites. Although the magnitude of catches was quite different, trends in catch rates were similar with dramatic declines at both near-shore and off-shore sites from August 2 to September 16. Catch rates in 2008 , however, declined most notably from early June to late July (Burdick and VanderKooi, 2010).

Age-1 sucker catch rates peaked at sites with water depths between 2.0 and $3.0 \mathrm{~m}$ in 2009. This is considerably less than depths at which catch rates were maximized in 2007 (4.0$5.0 \mathrm{~m}$ ) and 2008 (6.0-7.0 m; Burdick and others 2008; Burdick and VanderKooi, 2010). The difference partially can be explained by the paucity of age-1 suckers collected in the deep water areas in the western third of the lake from Howard Bay to Eagle Point in 2009, an area of high age-1 sucker concentrations in 2007 and 2008 (Burdick and others, 2008b; Burdick and VanderKooi, 2010). In 2009, age-1 suckers primarily were caught in relatively shallow nearshore environments along the western and eastern shores.

Although unsubstantiated by physical recaptures, spatial patterns in catch rates in 2007 and 2008 indicate that age-1 suckers may have migrated towards deep water areas along the western shore in late June and then away from these same areas in early July. Coincident to suckers leaving these areas were sharp decreases in DO concentrations in Eagle Ridge Trench. One biological hypothesis proposed as a driving force for this apparent spring-time attraction to the western part of the lake is the availability of large benthic invertebrates in Eagle Ridge Trench and Ball Bay (J. Carter, U.S. Geological Survey, written commun., 2009). Although we did see relatively high catches in the western lake in 2009, age-1 suckers were not concentrated in deep water areas in Eagle Ridge Trench as they were in 2008. Rather, most age-1 catches occurred in relatively shallow Shoalwater, Howard, and Ball Bays. Nevertheless, catches in the western lake exhibited essentially the same pattern as catches in 2007 and 2008. Catch rates remained high until mid to late-July when DO concentrations at Eagle Point and Mid-North rapidly declined, after which catches primarily occurred along the eastern shore and in off-shore areas in the main lake. Regardless of why age-1 suckers congregate along the western shore, the consistent pattern throughout 3 years of sampling indicates that juvenile suckers actively avoid areas of low DO concentrations, especially in deep water areas along the western shore in July and August.

Although temporal trends in catch rates indicate age-1 suckers move away from the trench as DO concentrations decrease to less than sublethal thresholds (Loftus, 2001), they do not move into the relatively better conditions that tributaries could provide. In fact, age-1 and age- 2 catch rates in the tributaries virtually mirrored overall catch rates throughout Upper Klamath Lake. This would seem to dispel the hypothesis that the near disappearance of age-1 suckers in mid-July, coincident with decreasing DO concentrations, is due to these fish entering lake tributaries. The increased effort in off-shore areas and tributaries did not result in high catch rates as water quality declined in near-shore sites. This suggests that juvenile suckers are not moving off-shore to avoid poor water quality and as a result may experience high mortality. It is possible that the discrepancy between age-1 catch rates in the spring and late summer is simply a matter of seasonal changes in detection probability; however, we believe the temporal trends in catch rates is the result of declining abundance.

One of the most interesting findings from 2009 was the redetection of an age- 1 sucker tagged in Short Creek on June 4 and detected moving up the Link River fish ladder on August 5, more than $30 \mathrm{~km}$ away (U.S. Geological Survey, unpub. data, 2009). This observation, coupled with remote detections in the Williamson River of age-1 suckers tagged in the restored 
Williamson River delta, suggest that long distance movement by age-1 suckers is possible (U.S. Geological Survey, unpub. data, 2009). Evidence of long-distance migrations supports claims that seasonal changes in localized juvenile sucker catch rates may partially be the result of age-1 and older juvenile suckers avoiding poor water quality. This is the first recapture of any PIT tagged age-1 sucker in Upper Klamath Lake by remote detection arrays, and the first evidence that age-1 suckers are capable of ascending the Link River fish ladder. Due to the extensive PIT tag infrastructure around spawning locations along the eastern shore of Upper Klamath Lake and in the Williamson and Sprague Rivers, it is imperative that future work focus on capturing and PIT tagging age- 1 and older juveniles in order to provide critical juvenile sucker movement and survival data.

There is evidence that the relatively abundant 2006 cohort, which resulted in 11 percent of the juvenile sucker catch in 2008 (age-2 suckers; Burdick and VanderKooi, 2010), may have experienced high mortality or individuals have grown too large to be detected in our gear between their second and third year. We collected a maximum of three suckers ( 1 percent of the 2009 juvenile sucker catch) that, based on their length, were judged to be from the 2006 year class. This result comes despite the use of large-meshed fyke nets aimed at capturing older juvenile suckers at a subset of our sample sites throughout the field season. These nets were, however, successful at capturing three of the seven age-2 suckers caught in 2009.

\section{Distribution of Age-0 Suckers}

Similar to other years, most age-0 suckers were collected in shallow water in both nearshore and off-shore environments. In 2009, our catch rates peaked in 1.0-2.0 m of water, which is deeper than what was reported in $2008(<1.0 \mathrm{~m})$ and shallower than what was reported in 2007 (2.0-3.0 m; Burdick and others, 2008b). Still, our results support past research that indicated age-0 suckers affinity for relatively shallow water within Upper Klamath Lake (Buettner and Scoppettone, 1990). Our 2009 sampling design allowed for continuous assessment of near-shore and off-shore habitat use by age-0 suckers. Hendrixson and others (2007) and Burdick and others (2009) collected age-0 suckers in both near-shore and off-shore environments but reported the more frequent use of near-shore environments. Our results corroborate these findings as mean weekly catch rates were nearly always slightly higher in near-shore environments than off-shore habitats.

The timing of the first age- 0 detection and overall age- 0 species composition was similar to what was reported in 2008. The median naïve occupancy rates were conspicuously higher in 2009 than 2008: 29.5 versus 10.5. This probably is due to increased sampling effort at each site. In 2008, spring and late-summer sampling consisted of setting one net per site, whereas three nets were set at each site in 2009 . We believe this is the likely explanation because overall catch rates were similar between years. 
Age-0 suckers were detected earlier in the Williamson River than in Upper Klamath Lake, which may simply be due to the proximity of the sampling site to known upstream spawning locations. Due to the small number of age- 0 suckers caught (8), and relatively high number of tributaries sampled (7), we were unable to make robust conclusions about age- 0 sucker tributary use. Despite this limitation of our data, it is clear age-0 suckers use tributary habitat, albeit in low densities. In addition, the discrepancies between low age- 0 sucker catch rates in tributaries in September 2009 and the relatively high age-1 sucker catch rates in spring reported by Markle and Simon (1993) and USGS (this report) suggest that subadult suckers may migrate to tributaries from other habitats between autumn and early spring.

\section{Juvenile Sucker Condition}

The high opercle deformity rates exhibited by age- 0 suckers ( 17 percent), is similar to deformity rates observed in 2008 (25 percent; Burdick and VanderKooi, 2010). The congruency of deformity rates between 2008 and 2009 is of concern, given their inconsistency with juvenile suckers collected during the early 1990s, when 4.7 percent of Lost River suckers and 1.4-3.1 percent of shortnose suckers exhibited opercle deformities (Plunkett and Snyder-Conn, U.S. Fish and Wildlife Service, written commun., 2000). It is important to understand why opercle deformities have increased because they have been shown to lower resistance to oxygen stress and predispose fish to infections by bacteria, parasites, and fungi (Galeotti and others, 2000; Beraldo and others, 2003). Although these deformities are common in hatchery raised fish and considered non-lethal, extended periods of low DO concentrations and abundant parasites may be a lethal combination for age-0 suckers in Upper Klamath Lake. Consistently lower opercle deformity rates for age- 1 and older juvenile suckers relative to age-0 suckers support this claim.

Although both Lost River and shortnose suckers grew throughout 2009, relative weight $\left(W_{r}\right)$ for suckers collected in Upper Klamath Lake in 2009 was slightly less than for suckers collected in 2006. Relatively high infection rates by parasitic anchor worms may provide an explanation. Anchor worm attachment has been correlated with infectious granulomas (rainbow trout; Berry and others, 1991), lesions, necrotic tissue, and liver damage in various fish species (Khalifa and Post, 1976). Simon and others (2009) reported that the prevalence of anchor worms in 2006 was lower on age-0 shortnose suckers than in any other year between 2002 and 2008, and on age-0 Lost River suckers than in any other year between 1997 and 2008. Only 4 percent of age- 0 suckers in our study were infected by anchor worms in 2008 as compared to 18 percent in 2009, potentially limiting growth and weight gain. In addition, anchor worm infection rates for age-1 and age-2 suckers substantially increased between 2008 and 2009. In 2008, only 1 percent of age- 1 suckers were infected by anchor worms, whereas 50 percent of captured age- 1 suckers were parasitized in 2009. Likewise, 17 percent of age- 2 suckers were infected in 2008, whereas 43 percent were infected in 2009. Simon and others (2009) also reported high rates of anchor worm parasitism on juvenile shortnose (38 percent) and Lost River suckers (41 percent) collected in the same general area between August and October from 1997 to 2008 (Simon and others, 2009). Infection intensity (anchor worms per fish) also substantially increased between 2008 and 2009. In 2008, maximum infection intensity was 1 (Burdick and VanderKooi, 2010), whereas in 2009 mean infection intensity was 2.6 (anchor worms per fish) with a range of 1-11. Likewise, the range for the three age-2 suckers that were infected with anchor worm was high (9-12). 
An increased prevalence and intensity of anchor worm parasitism between 2008 and 2009 may not be cause for alarm. Some evidence suggests that anchor worm infections do not pose serious threats to overall fish health (Robinson and others, 1998). Additional research needs to be conducted to determine the effect anchor worms have on sucker health given the environmental conditions in Upper Klamath Lake.

\section{Community Structure}

Fish community structure and temporal patterns in catch per unit effort were similar in 2008 and 2009. Tui chub, which dominated the catch throughout 2008, were again captured in relatively high abundances and comprised most of the catch during the first several sampling weeks. Fathead minnow, however, dominated catches in 2009 especially in August and September. This was in marked contrast to 2008. The dominance by fathead minnow in late summer, and especially in the north strata, led to extremely low diversity measures and is concerning due to their ability to prey on larval suckers (Markle and Dunsmoor, 2007).

\section{Acknowledgments}

We thank Daniel Brown, Travis Ciotti, Megan Dethloff, Terra Kemper, James Latshaw, Randal Lodges, Nick Miller, Anna Willard, and Jolene Willis of the U.S. Geological Survey, Klamath Falls Field Station for help with data collection. Debbra Wahrenbrock, Debbie Caldwell, and Don McDonnell of Oregon Institute of Technology, assisted with juvenile sucker species identification. We also thank Greta Blackwood, Amari Dolan-Caret, and Alta Scott of the U.S. Geological Survey, Klamath Falls Field Station for help with database development and management. This work was funded by the Bureau of Reclamation (Interagency Agreement 04AA204032) and the U.S. Geological Survey.

\section{References Cited}

Anderson, R.O., and Neumann, R.M., 1996, Length, weight, and associated structural indices in Murphy B.R., and Willis, D.W., eds., Fisheries Techniques, $2^{\text {nd }}$ edition: American Fisheries Society, Bethesda, Maryland.

Bailey, L.L., Simons, T.R., and Pollock, K.H., 2004, Spatial and temporal variation in detection probability of plethodon salamanders using the robust capture-recapture design: Journal of Wildlife Management, v. 68, p. 14-24.

Banish, N.P., Adams, B.J., Shivley, R.S., Mazur, M.M, Beauchamp, D.A., and Wood, T.M., 2009, Distribution and habitat associations of radio-tagged Lost River and shortnose suckers in Upper Klamath Lake, Oregon: Transactions of the American Fisheries Society, v. 138, p.153168.

Beraldo, P., Pinosa, M., Tibaldi, E., and Canavese, B., 2003, Abnormalities of the operculum in gilthead sea bream (Sparus aurata): morphological description: Aquaculture, v. 220, p. 89-99.

Berry, C.R., Babey, G.J., and Shrader, T., 1991, Effect of Lernaea cyprinacea (crustacean: copepoda) on stocked rainbow trout (Oncorhynchus mykiss): Journal of Wildlife Diseases, v. 27, no. 2, p. 206-213.

Buettner, M., and Scoppettone, M.M., 1990, Life history and status of Catostomids in Upper Klamath Lake, Oregon: Oregon Department of Fish and Wildlife, Klamath Tribe, and National Fisheries Research Center, Reno, Nevada. 
Burdick, S.M., Wilkens, A.X., and VanderKooi, S.P., 2008a, Near-shore and off-shore habitat use by endangered, juvenile Lost River and shortnose suckers in Upper Klamath Lake, Oregon: 2006 data summary: U.S. Geological Survey Open-File Report 2007-1356, 30 p.

Burdick, S.M., Hendrixson, H.A., and VanderKooi, S.P., 2008b, Age-0 Lost River and shortnose sucker near-shore habitat use in Upper Klamath Lake, Oregon: a patch-occupancy approach: Transactions of the American Fisheries Society, v. 137, p. 417-430.

Burdick, S.M., Anderson, G.O., and VanderKooi, S.P., 2009, Spring and summer habitat use by endangered juvenile Lost River and shortnose suckers in Upper Klamath Lake, Oregon: 2007 annual report: U.S. Geological Survey Open-File Report 2009-1043, 56 p.

Burdick, S.M., and Vanderkooi, S.P., 2010, Temporal and spatial distribution of endangered juvenile Lost River and shortnose suckers in relation to environmental variables in Upper Klamath Lake, Oregon: 2008 annual data summary: U.S. Geological Survey Open-File Report 2010-1051, 36 p.

Galeotti, M., Beraldo, P., de Dominis, S., D’Angelo, L., Ballestrazzi, R., Musetti, R., Pizzoloito, S., and Pinosam, M., 2000, A preliminary histological and ultrastructural study of opercular anomalies in gilthead sea bream larvae (Sparus aurata): Fish Physiology and Biochemistry, v. 22, p.151-157.

Hendrixson, H.A., Burdick, S.M., and VanderKooi, S.P., 2007, Near-shore and offshore habitat use by endangered, juvenile Lost River and shortnose suckers in Upper Klamath Lake, Oregon: Annual report 2004: Report of U.S. Geological Survey, Western Fisheries Research Center, Klamath Falls Field Station to Bureau of Reclamation, Mid-Pacific Region, Klamath Falls, Oregon.

Hilborn, R., and Walters, C.J., 1992, Quantitative Fisheries Stock Assessment: Choice, Dynamics and Uncertainty: New York, Chapman and Hall.

Khalifa, K.A., and Post, G., 1976, Histopathological effect of Lernaea cyprinacea (a copepod parasite) on fish: The Progressive Fish-Culturist, v. 38, no. 2, p. 110-113.

Lindenberg, M.K., Hoilman, G.R., and Wood, T.M., 2008, Water quality conditions in Upper Klamath Lake, Oregon, 2006: U.S. Geological Survey Open-File Report 2008-5201, 23 p.

Loftus, M.E., 2001, Assessment of potential water quality stress to fish: Report by R2 Resources Consultants to Bureau of Indian Affairs, Portland, Oregon.

MacKenzie, D.L., 2005, Was it there? Dealing with imperfect detection for species presence/absence data: Australian and New Zealand Journal of Statistics, v. 47, p. 65-74.

MacKenzie, D.L., Nichols, J.D., Royle, J.A., Pollock, K.H., Bailey, L.L., and Hines, J.E., 2006, Occupancy estimation and modeling: inferring patterns and dynamics of species occurrence:

San Francisco, California, Elsevier Publishing, 324 p.

Markle, D.F., and Dunsmoor, L., 2007, Effects of habitat volume and fathead minnow introduction on larval survival of two endangered sucker species in Upper Klamath Lake, Oregon: Transactions of the American Fisheries Society, v. 136, p. 567-579.

Markle, D.F., Cavalluzzi, M.R., and Simon, D.C., 2005, Morphology and taxonomy of Klamath Basin suckers (Catostomidae): Western North American Naturalist, v. 65, p. 473-489.

Markle, D.F., and Simon, D.C., 1993, Preliminary studies of systematics and juvenile ecology of Upper Klamath Lake suckers: Final Report: Oregon State University, Corvallis, Oregon.

Martin, B.A., and Saiki, M.K., 1999, Effects of ambient water quality on the endangered Lost River sucker in Upper Klamath Lake, Oregon: Transactions of the American Fisheries Society, v. 128, p. 953-967. 
McCune, B., and Grace, J.B., 2002, Analysis of Ecological Communities: MJM Software Design, Gleneden Beach, Oregon.

Mulligan, T.J., and Mulligan, H.L., 2007, Habitat utilization and life history patterns of fishes in Upper Klamath National Wildlife Refuge Marsh, Fourmile Creek and Odessa Creek, Oregon: Final Report: Humboldt State University, Arcata, CA.

National Research Council, 2004, Endangered and threatened fishes in the Klamath River Basin: The National Academies Press, Washington, D.C.

Peterson, J.T., Thurow, R.T., and Guzevich, J.W., 2004, An evaluation of multipass electrofishing for estimating the abundance of stream dwelling salmonids: Transactions of the American Fisheries Society, v. 133, p. 462-475.

Robinson, A.T., Hines, P.P., Sorensen, J.A., and Bryan, S.B., 1998, Parasites and fish health in a desert stream, and management implications for two endangered species: North American Journal of Fisheries Management, v. 18, p. 599-608.

Saiki, M.K., Monda, D.P., and Bellerud, B.L., 1999, Lethal levels of selected water quality variables to larval and juvenile Lost River and shortnose suckers: Environmental Pollution, v. 105 , p. 37-44.

Simon, D.C., and Markle, D.F., 2001, Ecology of Upper Klamath Lake shortnose and Lost River suckers: Annual survey of abundance and distribution of age-0 shortnose and Lost River suckers in Upper Klamath Lake, 2000 Annual Report: Report of Oregon Cooperative Research Unit, Department of Fisheries and Wildlife, Oregon State University to U.S. Biological Resources Division, U.S. Geological Survey, Corvallis, Oregon and Klamath Project, Bureau of Reclamation, Klamath Falls, Oregon.

Simon, D.C., and Markle, D.F., 2002, Ecology of Upper Klamath Lake shortnose and Lost River suckers: Annual survey of abundance and distribution of age-0 shortnose and Lost River suckers in Upper Klamath Lake-2001 Annual Report: Report of Oregon Cooperative Research Unit, Department of Fisheries and Wildlife, Oregon State University to U.S. Biological Resources Division, U.S. Geological Survey, Corvallis, Oregon and Klamath Project, Bureau of Reclamation, Klamath Falls, Oregon.

Simon, D.C., and Markle, D.F., 2006, Ecology of Upper Klamath Lake shortnose and Lost River suckers: Annual survey of abundance and distribution of age- 0 shortnose and Lost River suckers in Upper Klamath Lake - 2005 Annual Report: Report of Oregon Cooperative Research Unit, Department of Fisheries and Wildlife, Oregon State University to U.S. Biological Resources Division, U.S. Geological Survey, Corvallis, Oregon and Klamath Project, Bureau of Reclamation, Klamath Falls, Oregon.

Simon, D.C., Terwilliger, M.R., Murtaugh, P., and Markle, D.F., 2000a, Larval and juvenile ecology of Upper Klamath Lake suckers: 1995-1998: Corvallis, Oregon, Department of Fisheries and Wildlife, Oregon State University.

Simon, D.C., Terwilliger, M.R., and Markle, D.F., 2000b, Ecology of Upper Klamath Lake shortnose and Lost River suckers: Annual survey of abundance and distribution of age-0 shortnose and Lost River suckers in Upper Klamath Lake, 1999 Annual Report: Report of Oregon Cooperative Research Unit, Department of Fisheries and Wildlife, Oregon State University to U.S. Biological Resources Division, U.S. Geological Survey, Corvallis, Oregon and Klamath Project, Bureau of Reclamation, Klamath Falls, Oregon.

Simon, D.C., Terwilliger, M.R., and Markle, D.F., 2009, Larval and juvenile ecology of Upper Klamath Lake suckers: 2004 to 2008 Final Report: Report of Oregon Cooperative Research Unit, Department of Fisheries and Wildlife, Oregon State University to U.S. Biological 
Resources Division, U.S. Geological Survey, Corvallis, Oregon and Klamath Project, Bureau of Reclamation, Klamath Falls, Oregon.

Terwilliger, M.R., Simon, D.C., and Markle, D.F., 2004, Larval and juvenile ecology of Upper Klamath Lake suckers, 1995-2003: Corvallis, Oregon, Oregon Cooperative Research Unit, Department of Fisheries and Wildlife, Oregon State University.

Terwilliger, M.R., Simon, D.C., and Markle, D.F., 2008, Ecology of Upper Klamath Lake shortnose and Lost River suckers, 2006 Annual Report: Report of Oregon Cooperative Research Unit, Department of Fisheries and Wildlife, Oregon State University to U.S. Biological Resources Division, U.S. Geological Survey, Corvallis, Oregon and Klamath Project, Bureau of Reclamation, Klamath Falls, Oregon.

U.S. Geological Survey, 2009, National Water Information System Web Interface: accessed August 11, 2009, at. http://waterdata.usgs.gov/nwis/nwisman/?site_no=11502500\&agency_cd $=U S G S$.

VanderKooi, S.P., and Buelow, K.A., 2003, Near-shore habitat use by endangered juvenile suckers in Upper Klamath Lake, Oregon: Annual report 2001: U.S. Geological Survey, Western Fisheries Research Center, Klamath Falls Field Station, Klamath Falls, Oregon.

VanderKooi, S.P., Herring, B.L., Coshow, R.H., and Hendrixson, H.A., 2006, Near-shore habitat use by endangered juvenile suckers in Upper Klamath Lake, Oregon: Annual report 20022003: U.S. Geological Survey, Western Fisheries Research Center, Klamath Falls Field Station, Klamath Falls, Oregon.

Weir, L.A., Royle, J.A., Nanjappa, P., and Jung, R.E., 2005, Modeling anuran detection and site occupancy on North American amphibian monitoring program (NAAMP) routes in Maryland: Journal of Herpetology, v. 39, p. 627-639.

Wood, T.M., Hoilman, G.R., and Lindenberg, M.K., 2006, Water quality conditions in Upper Klamath Lake, Oregon, 2002-2004: U.S. Geological Survey Scientific Investigations Report 2006-5209, 49 p.

Wood, T.M., Cheng, R.T., Gartner, J.W., Hoilman, G.R., Lindenberg, M.K., Wellman, R.E., 2008, Modeling hydrodynamics and heat transport in Upper Klamath Lake, Oregon, and implications for water quality: U.S. Geological Survey Scientific Investigations Report 20085076, 49 p. 


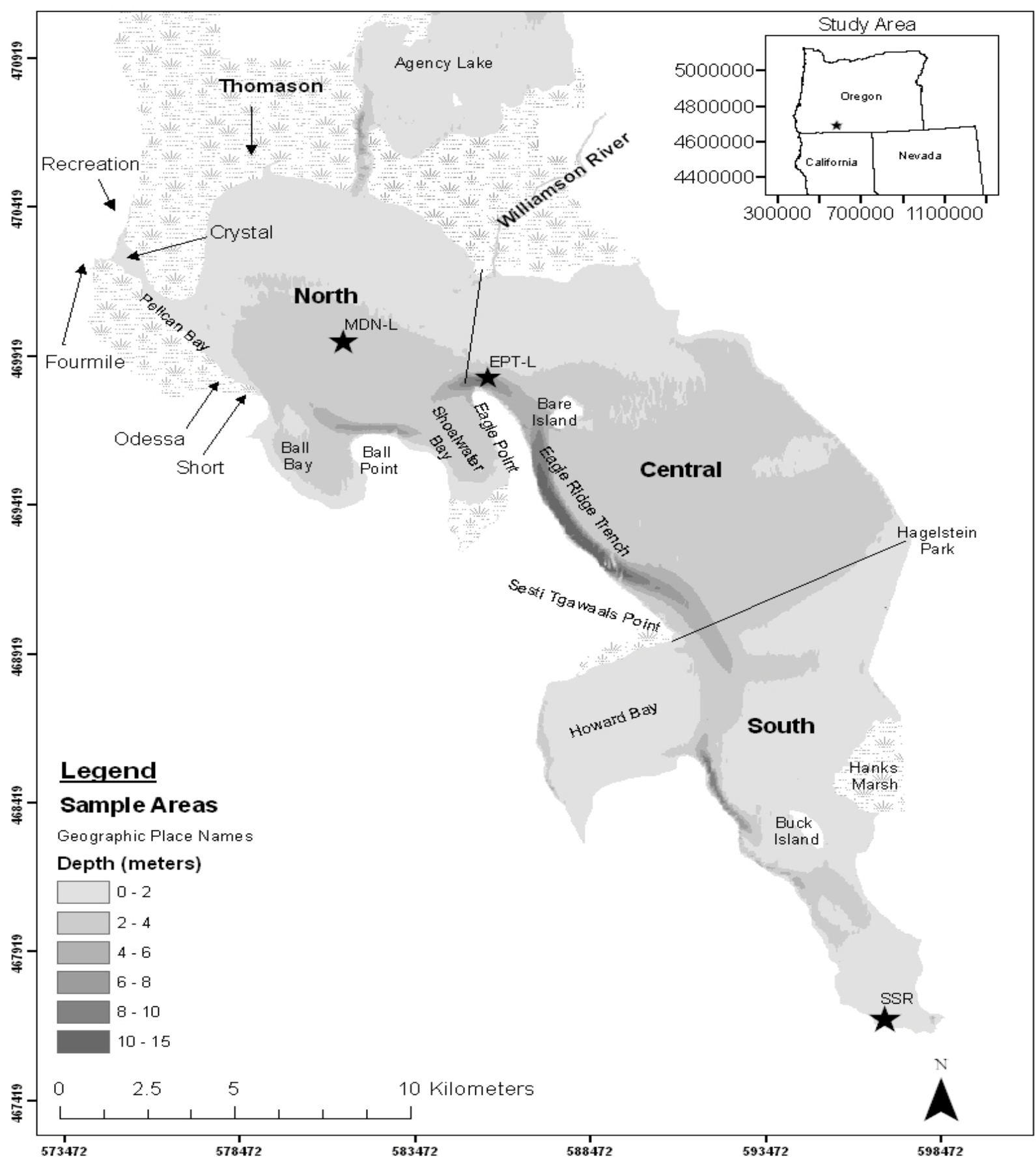

Figure 1. Map of Upper Klamath Lake study area and three defined areas of the lake. Sample sites were selected randomly from six strata, including near-shore and off-shore strata in the north, central, and south parts of the lake. Near-shore strata were considered areas within 100 meters of shore, whereas off-shore strata are areas more than 100 meters from shore. The location of all seven tributaries, including Short, Odessa, Fourmile, Recreation, Crystal, and Thomason Creeks, and the Williamson River also are shown. The lake was stratified by area to provide good coverage of the entire lake. Bathymetric layer is from U.S. Geological Survey (2004) and represents a lake elevation of 1,262.5 m (4,142.0 ft). Water-quality monitoring sites are shown with a star. 

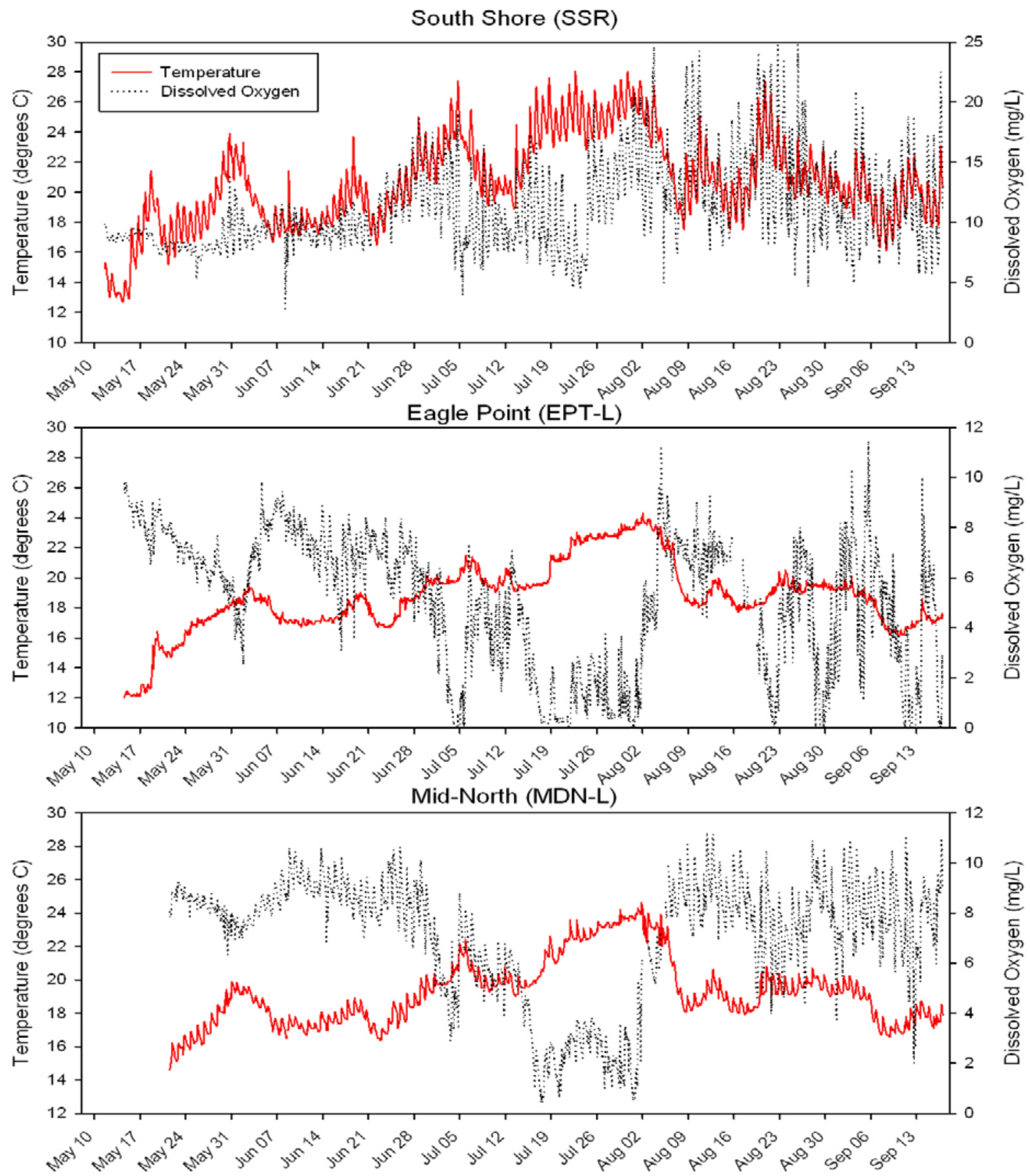

Figure 2. Dissolved oxygen concentrations (dotted black) and temperature (solid red) recorded each hour at three water-quality monitoring stations in Upper Klamath Lake, Oregon (U.S. Geological Survey, 2009). The location of these water-quality monitoring stations are shown in figure 1. These stations were selected to represent conditions in the southern tip of the Lake (South Shore, SSR), Eagle Point Trench (Eagle Point, EPT-L), and the area of Upper Klamath Lake located east of Ball Bay, Shoalwater Bay, Howard Bay, and Eagle Ridge Trench, and north of Buck Island (Mid-North, MDN-L). Note the different scale for dissolved oxygen for South Shore, compared to Eagle Point and Mid-North. 


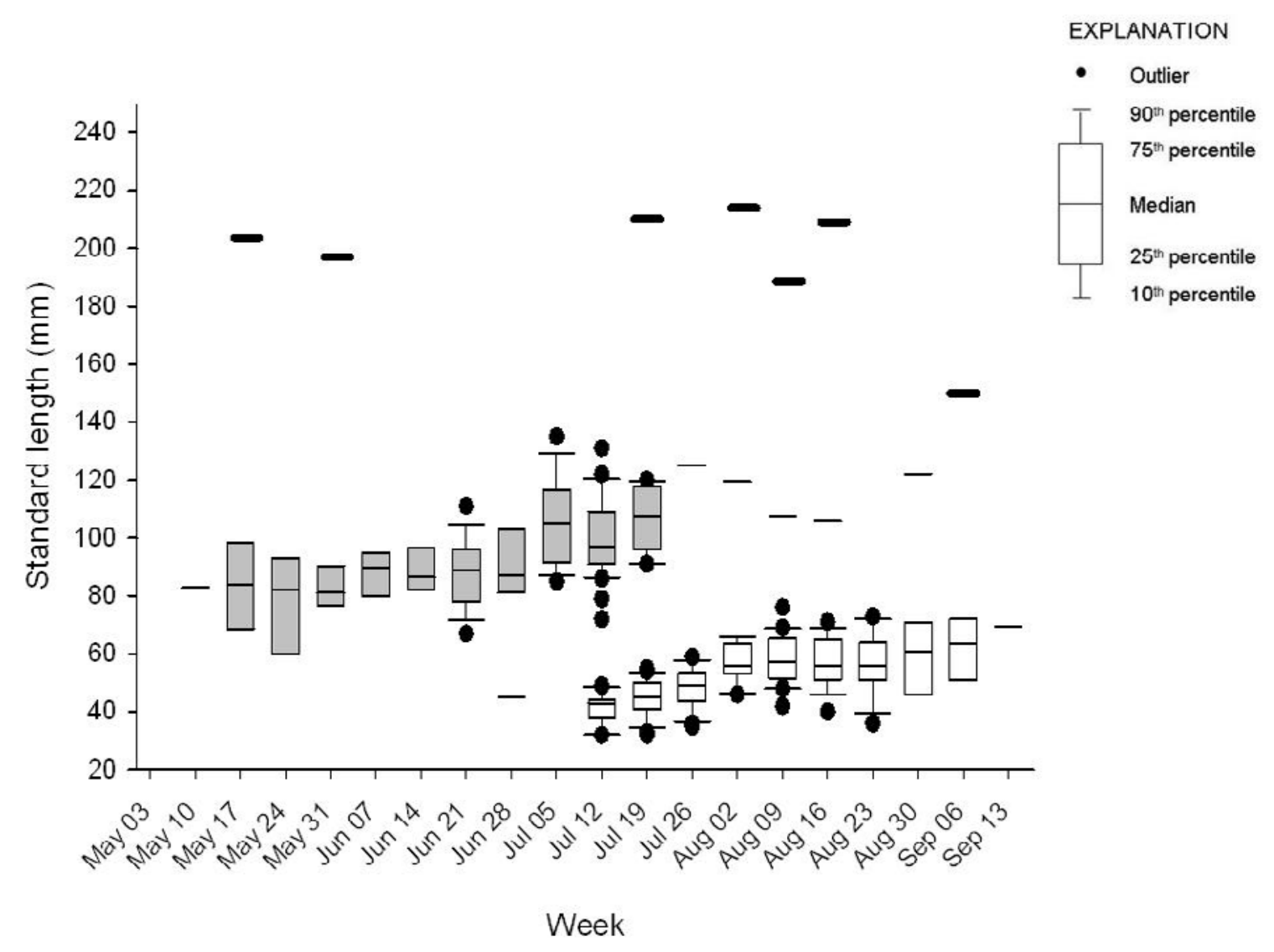

Figure 3. Standard lengths of juvenile suckers caught in trap nets set in Upper Klamath Lake and tributaries between May 4 and September 16, 2009. Three age classes are shown: age-0 suckers (white), age-1 suckers (grey), and age-2 suckers (thick black lines). Within each age class and each week, boxplots indicate the 25th, 50th, and 75 th percentiles, the whiskers indicate 5th and 95th percentiles and circles indicate outliers. 


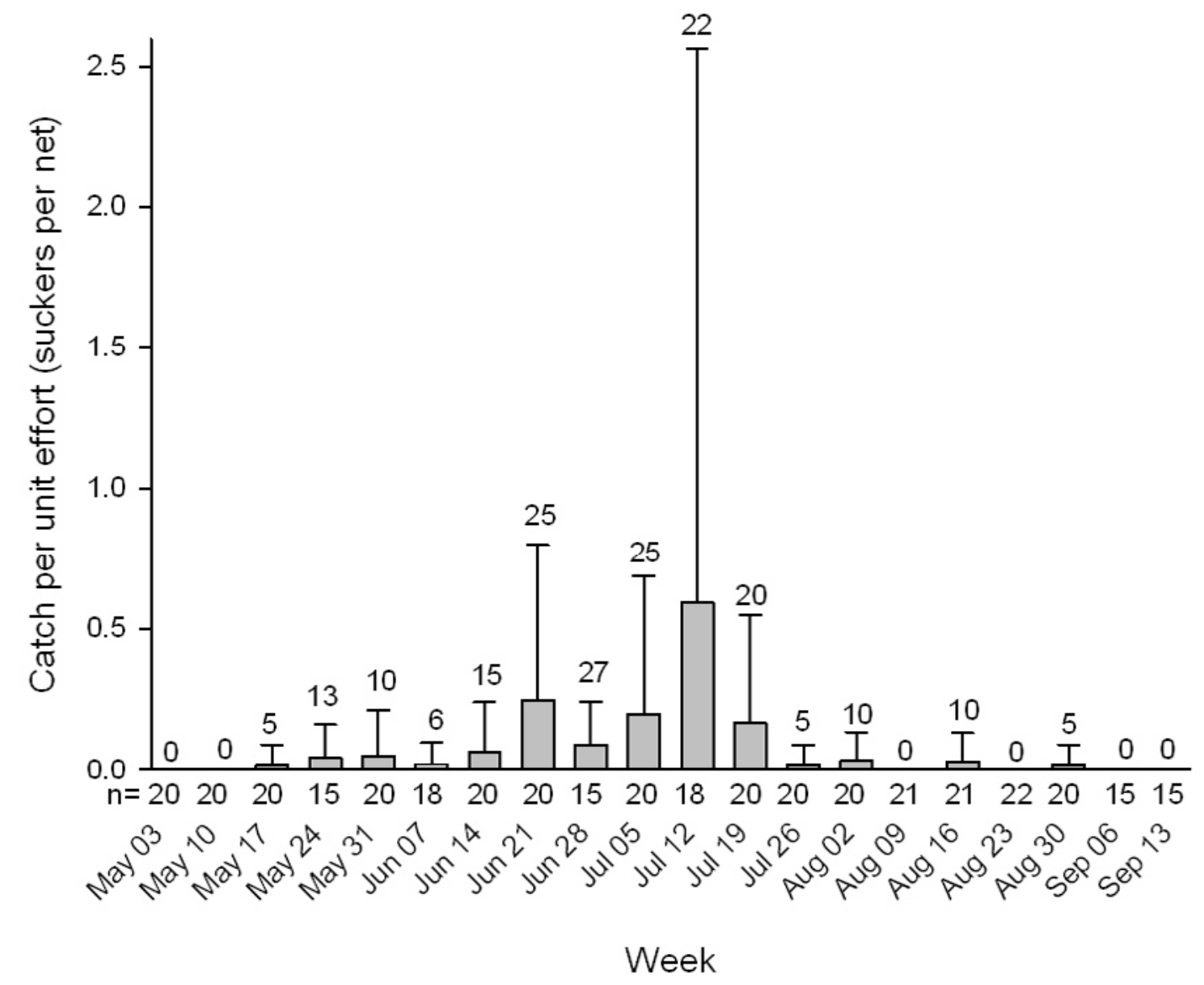

Figure 4. Mean $( \pm S D)$ weekly catch per unit effort (suckers per net) for age-1 suckers caught in trap nets set overnight in Upper Klamath Lake, Oregon, between May 3 and September 13, 2009. The percentage of sites at which at least one sucker was caught (naïve occupancy rate) and the number of sites sampled each week are given above and below the $x$-axis, respectively. At each site, between two and three nets were successfully set and pulled. 


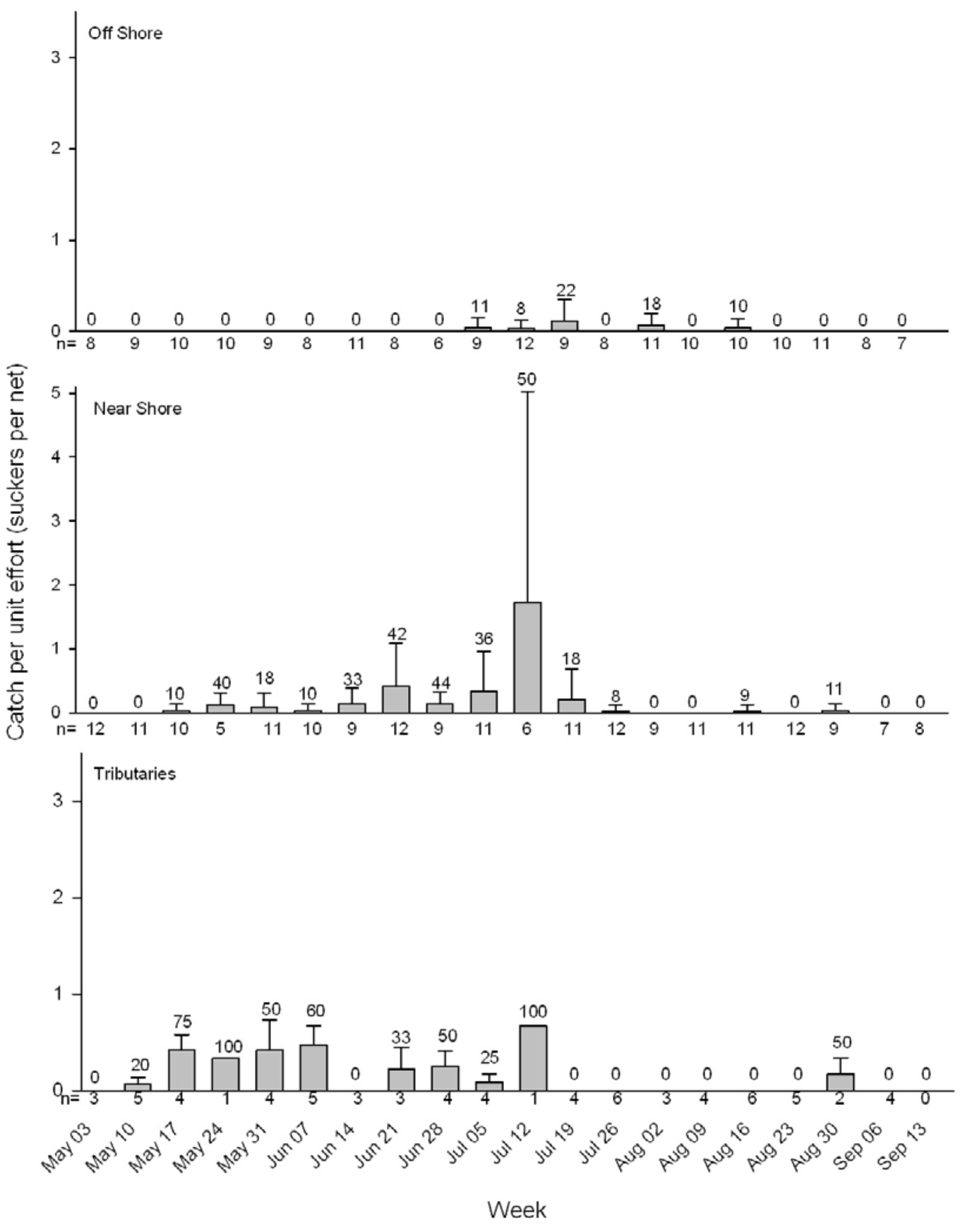

Figure 5. Mean $( \pm S D)$ weekly catch per unit effort (suckers per net) for age-1 suckers caught in trap nets set overnight in Upper Klamath Lake, Oregon, and its tributaries, between May 4 and September 16, 2009. Sites located within $100 \mathrm{~m}$ of shore (near-shore) are shown separately from sites located more than $100 \mathrm{~m}$ from shore (off-shore). The percentage of sites at which at least one sucker was caught (naïve occupancy rate) and the number of sites sampled each week are given above and below the $x$-axis, respectively. Note the different scale on the near-shore CPUE plot. 

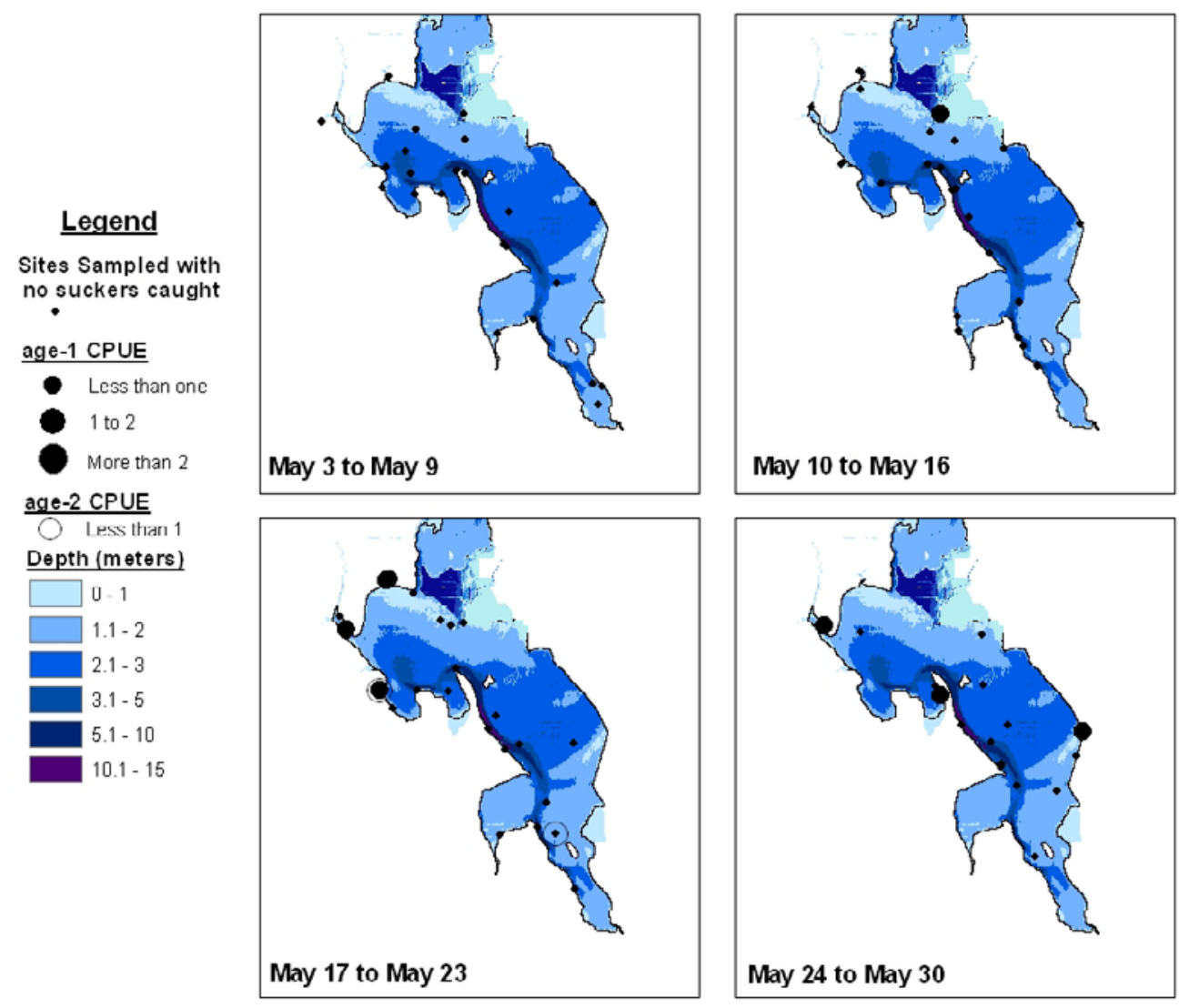

May 17 to May 23

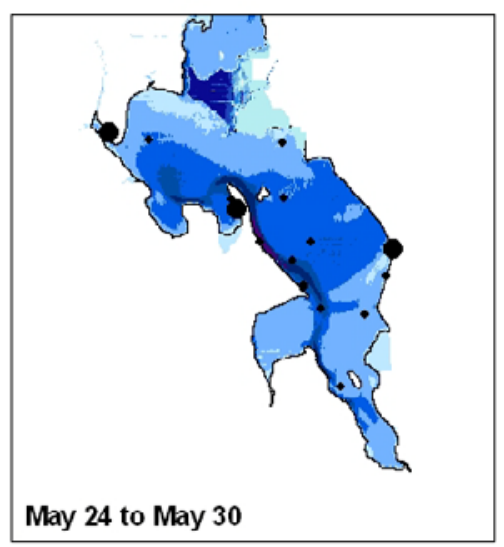

Figure 6. Location of sample sites and age-1 and age-2 sucker catch rates in Upper Klamath Lake, Oregon, and its tributaries, by week. Mean weekly catch per unit effort (CPUE; suckers per net) is divided into three categories for age-1 suckers (less than one, one to two, and more than two), and one category for age-2 suckers (less than one). Suckers were sampled between May 3 and September 16, 2009, using trap nets set overnight. Sample sites were selected to examine the distribution of juvenile suckers throughout the tributaries of Upper Klamath Lake, and both near-shore and off-shore habitat. Bathymetric layer is from Bureau of Reclamation (1997). All maps were created using a lake-surface elevation of $1,262.2 \mathrm{~m}(4,141.0 \mathrm{ft})$, which is typical in mid-July. 

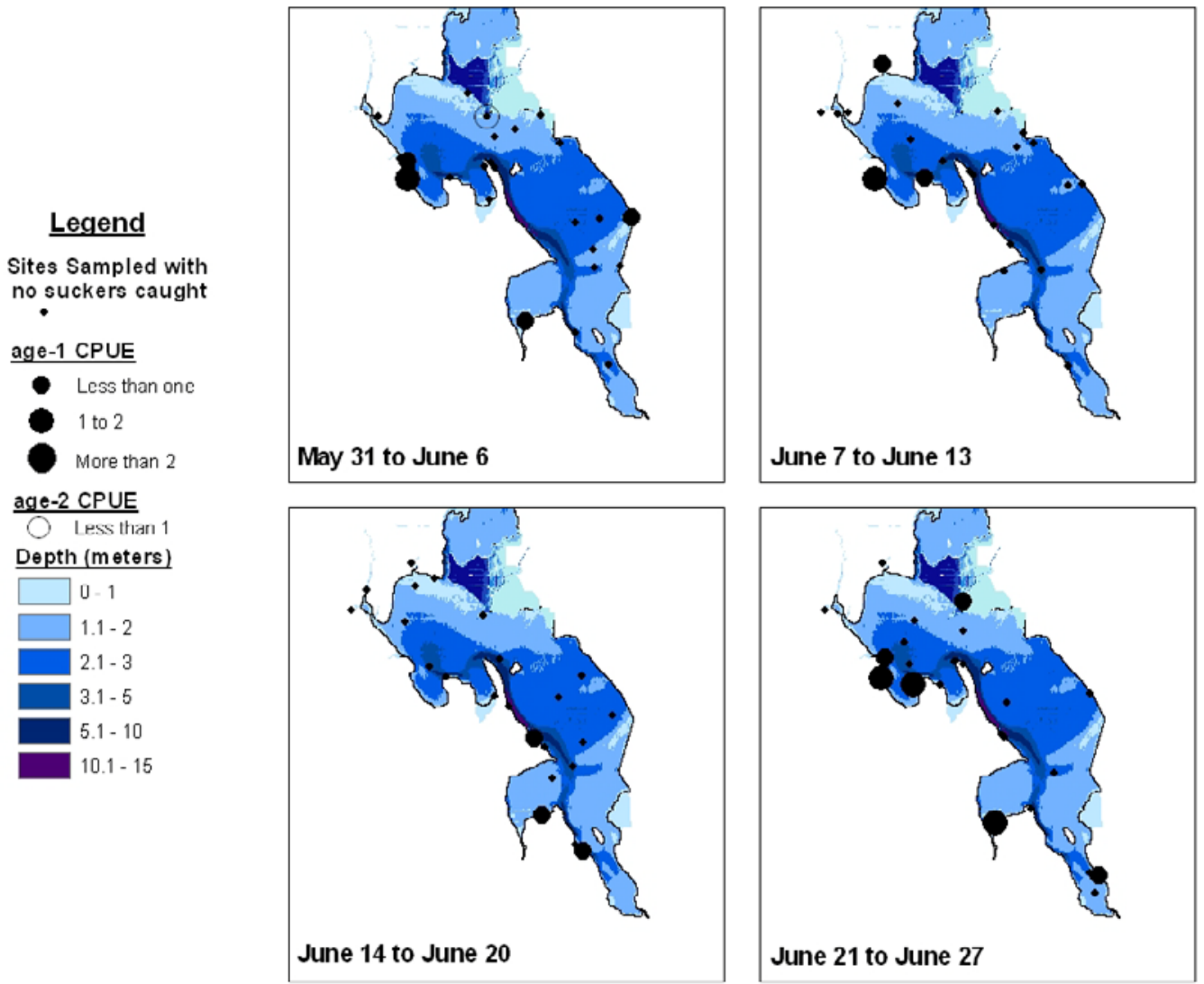

Figure 6. Continued 

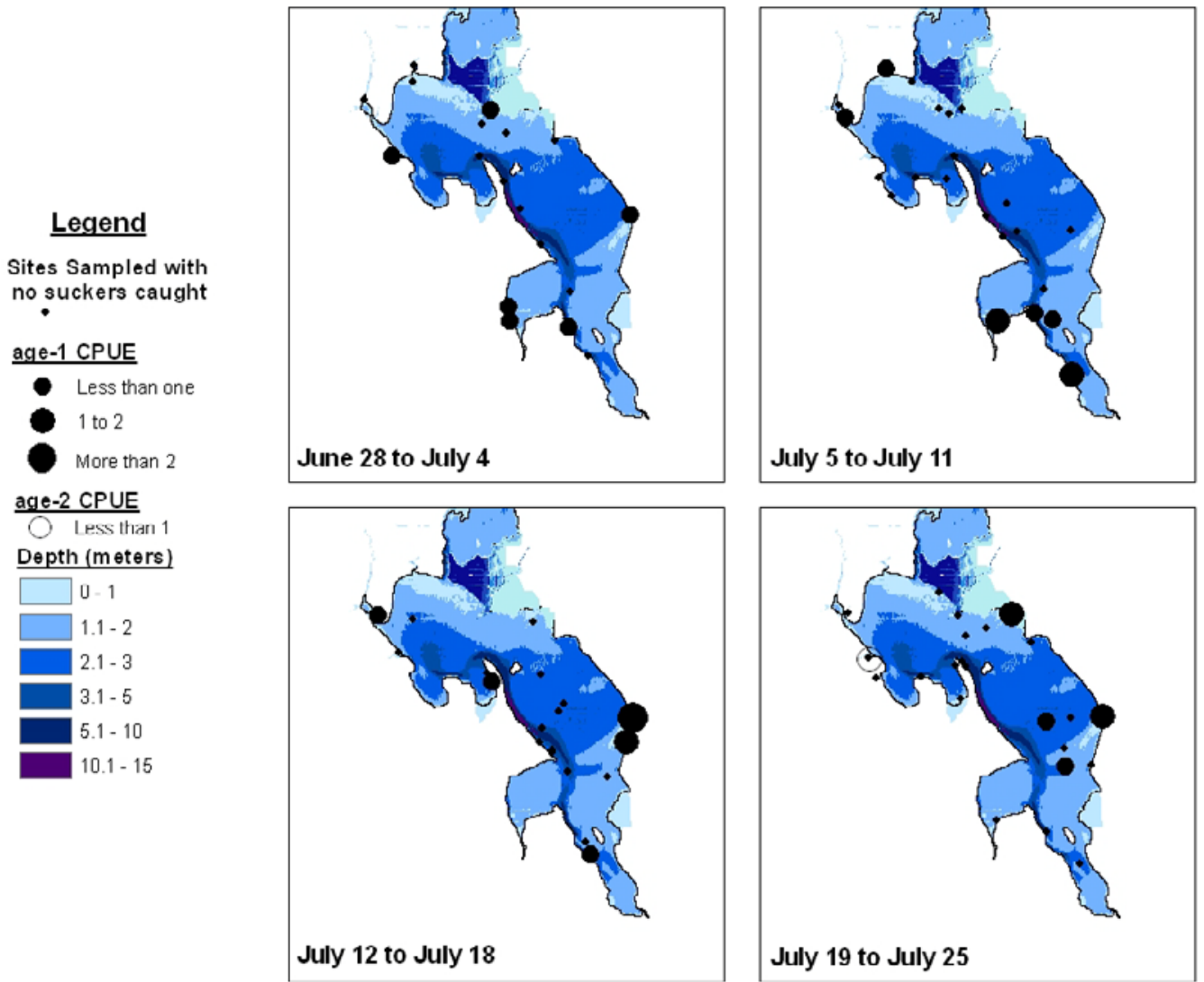

Figure 6. Continued 

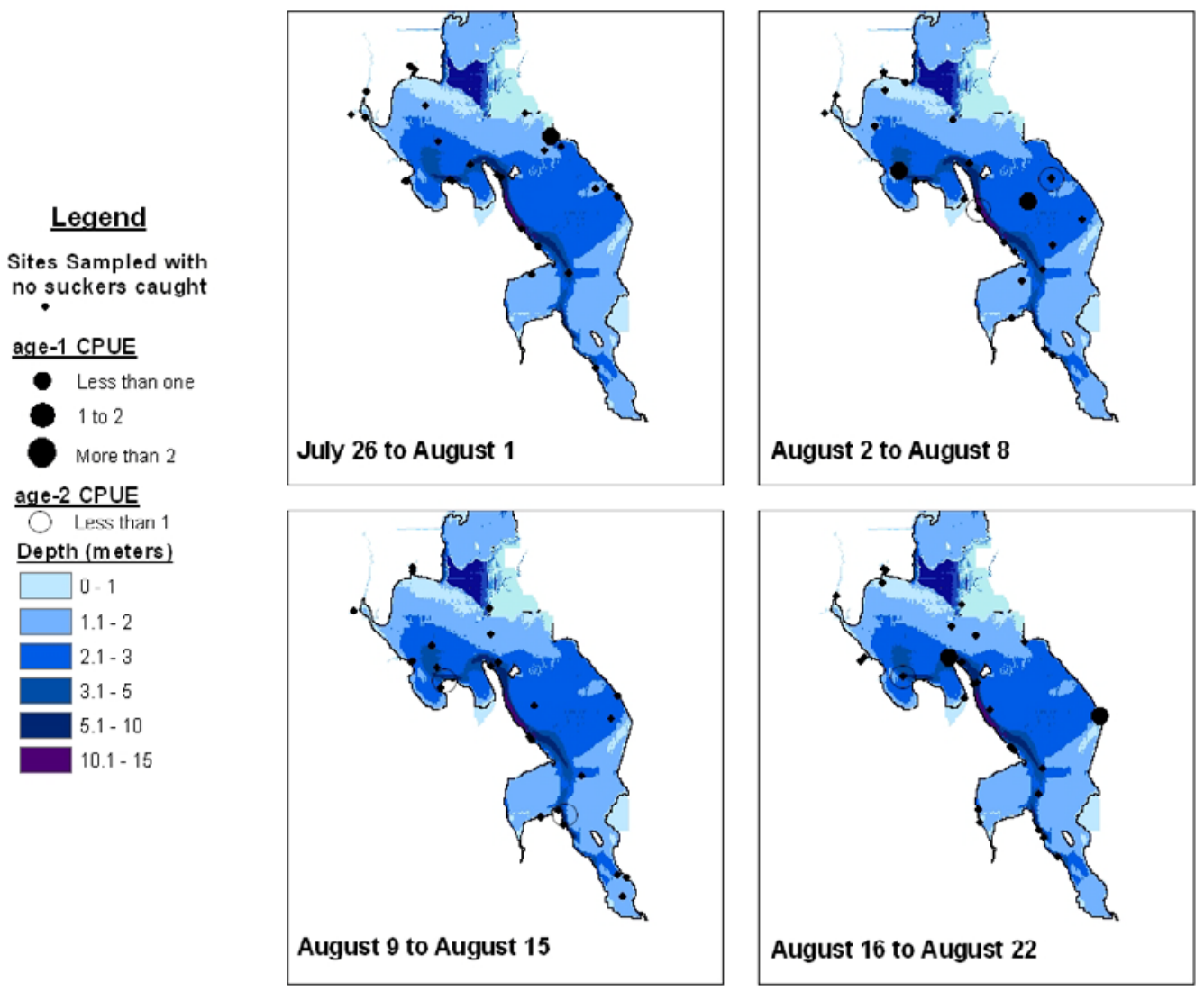

Figure 6. Continued 

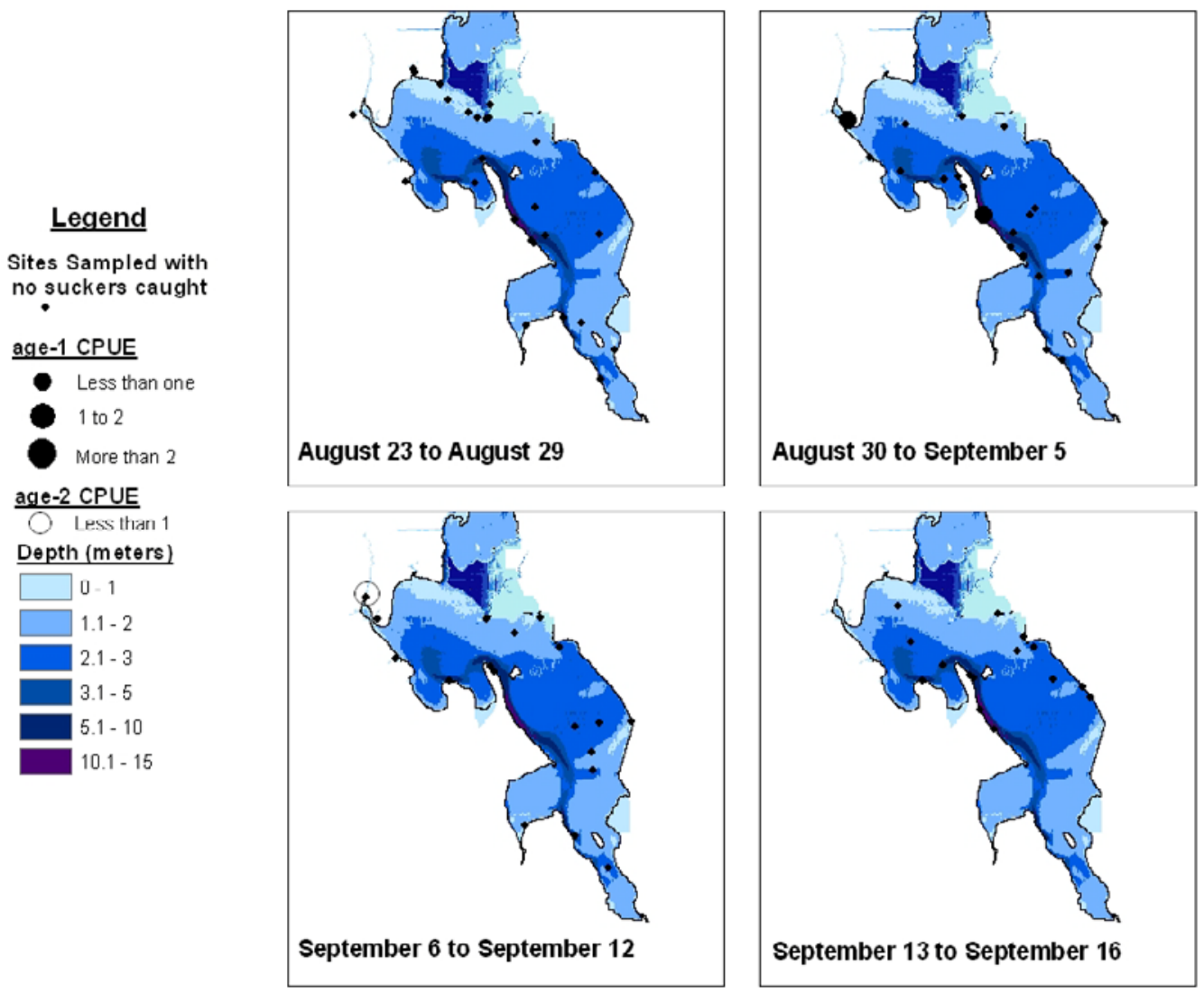

Figure 6. Continued 

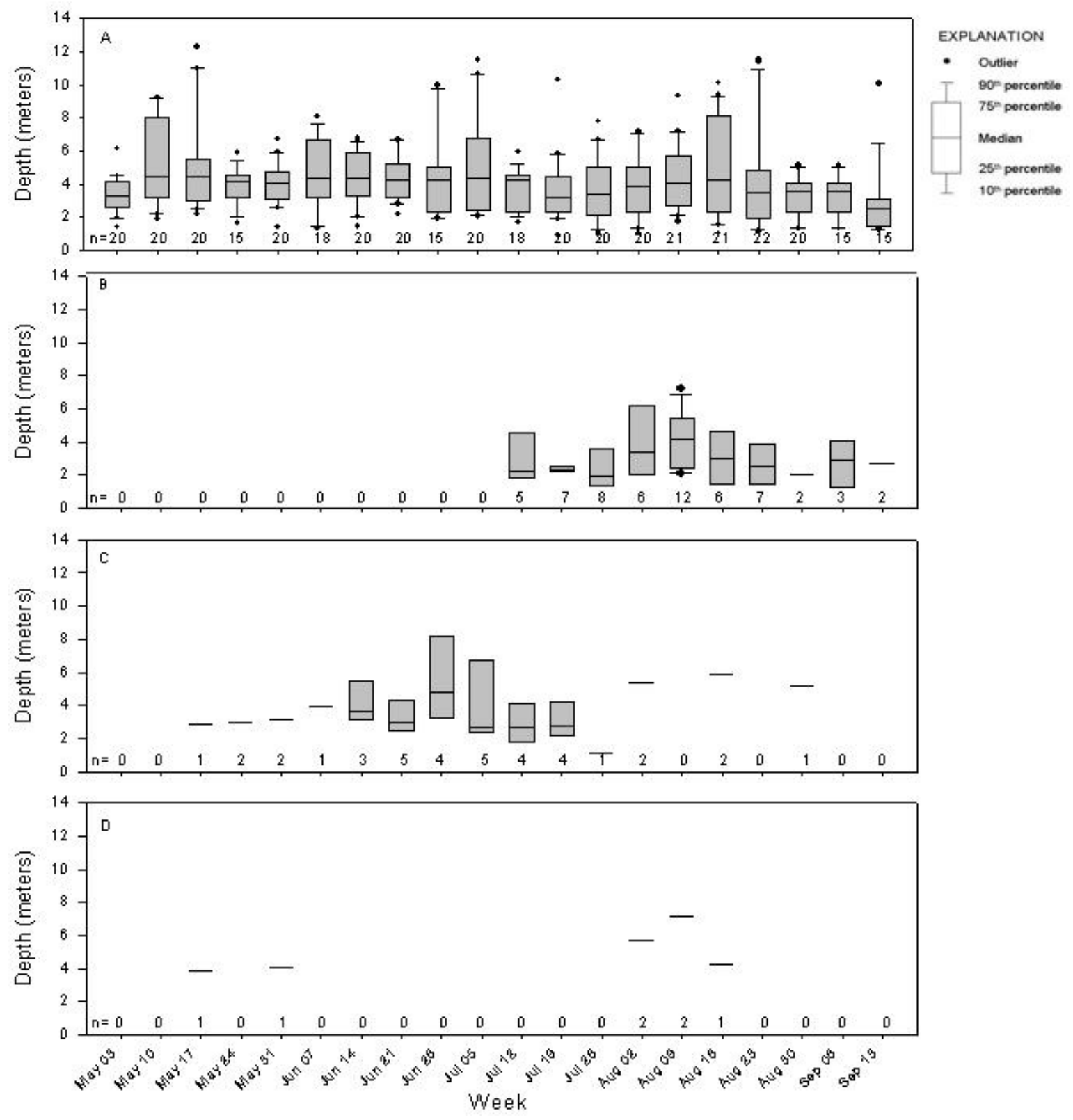

Figure 7. Depth for trap net sites (A), sites where age-0 suckers were caught $(B)$, sites where age-1 suckers were caught $(C)$, and sites where age-2 suckers were caught (D) are shown by week. Suckers were collected in trap nets set overnight in Upper Klamath Lake, Oregon, between May 4 and September 16, 2009. Boxplots show the median, 5th, 25th, 75th, and 95th percentiles and outliers (dots) in weekly data. The week sample sizes given along the $x$ axes (n) are for all sites sampled in plot $A$, and only for the sites where suckers were caught in plots $B, C$, and $D$. 


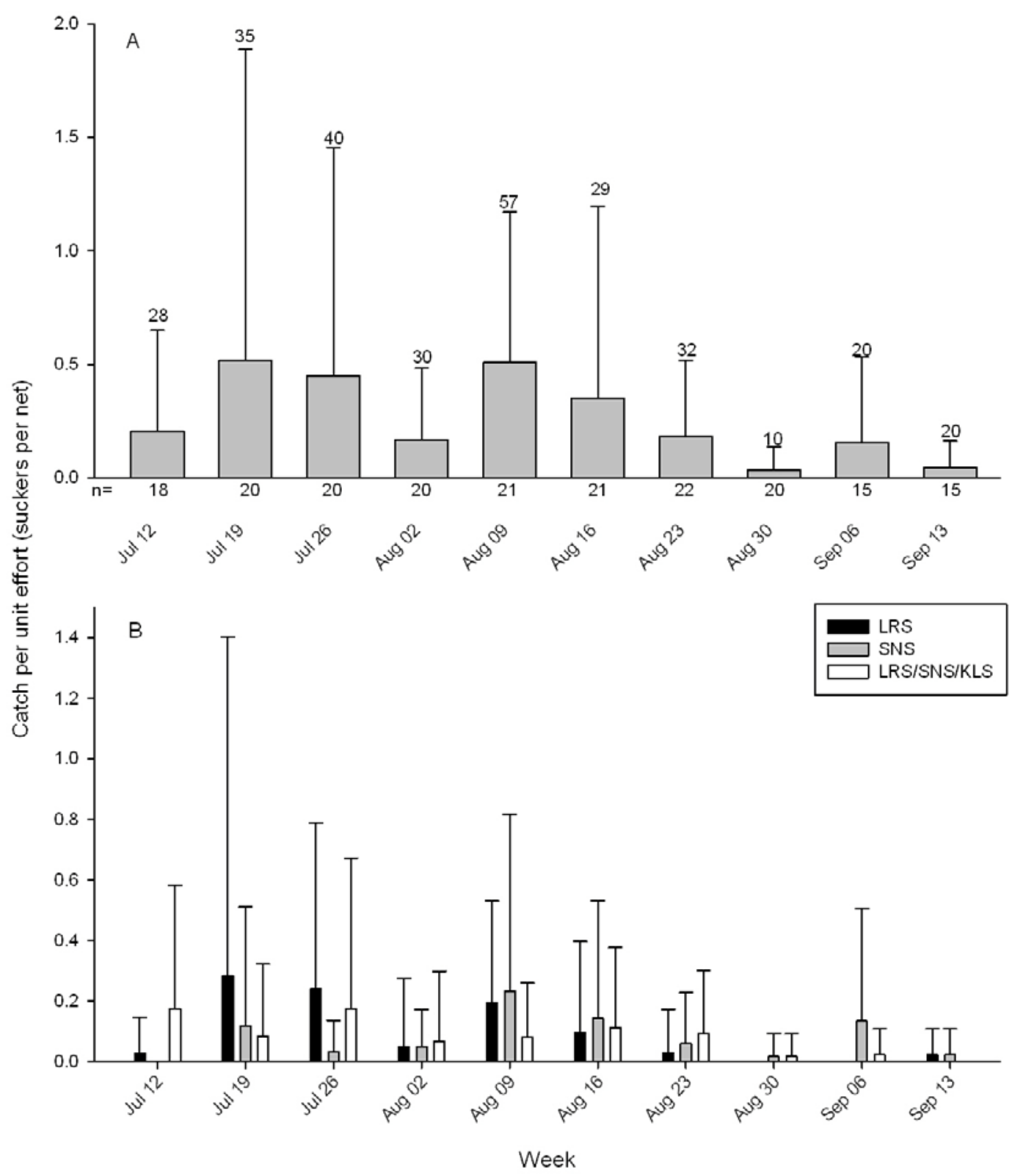

Figure 8. Mean $( \pm S D)$ weekly catch per unit effort (suckers per net) for age-0 suckers caught in trap nets set overnight in Upper Klamath Lake, Oregon, between July 12 and September 16, 2009 (A). The percentage of sites at which at least one sucker was caught (naïve occupancy rate) and the number of sites sampled each week are given above and below the x-axis, respectively. Mean $( \pm S D)$ weekly catch per unit effort for age-0 Lost River sucker (LRS, black), shortnose suckers (SNS, white), and suckers with characteristics of Lost River, shortnose or Klamath largescale suckers (LRS/SNS/KLS, grey) also are shown for the same time period (B). Juvenile suckers must be sacrificed for species identification. Therefore, to estimate catch per unit effort (suckers per net) for each species caught, we extrapolated using species identifications determined from a subset of sacrificed suckers equal to approximately one-third of the total catch. 

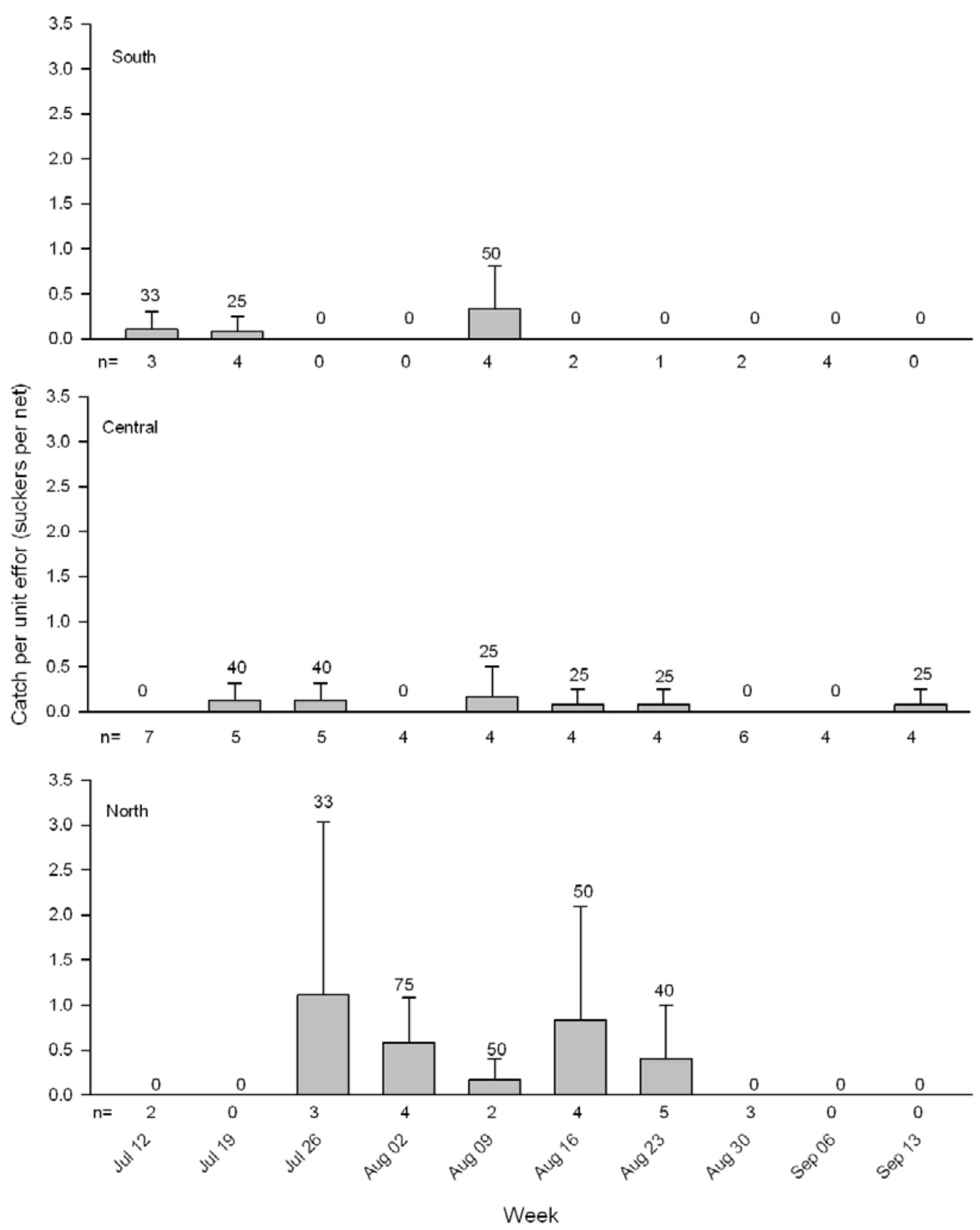

Figure 9. Mean $( \pm S D)$ weekly catch per unit effort (suckers per net) for age-0 suckers caught in trap nets in three off-shore areas (fig. 1) of Upper Klamath Lake, Oregon, between July 12 and September 16, 2009. Sample sites considered to be off-shore were more than $100 \mathrm{~m}$ off-shore. The percentages of sites at which at least one sucker was caught and the numbers of sites sampled each week are given above and below the $\mathrm{x}$-axis, respectively. Dates given are for the Sunday that started each week. 

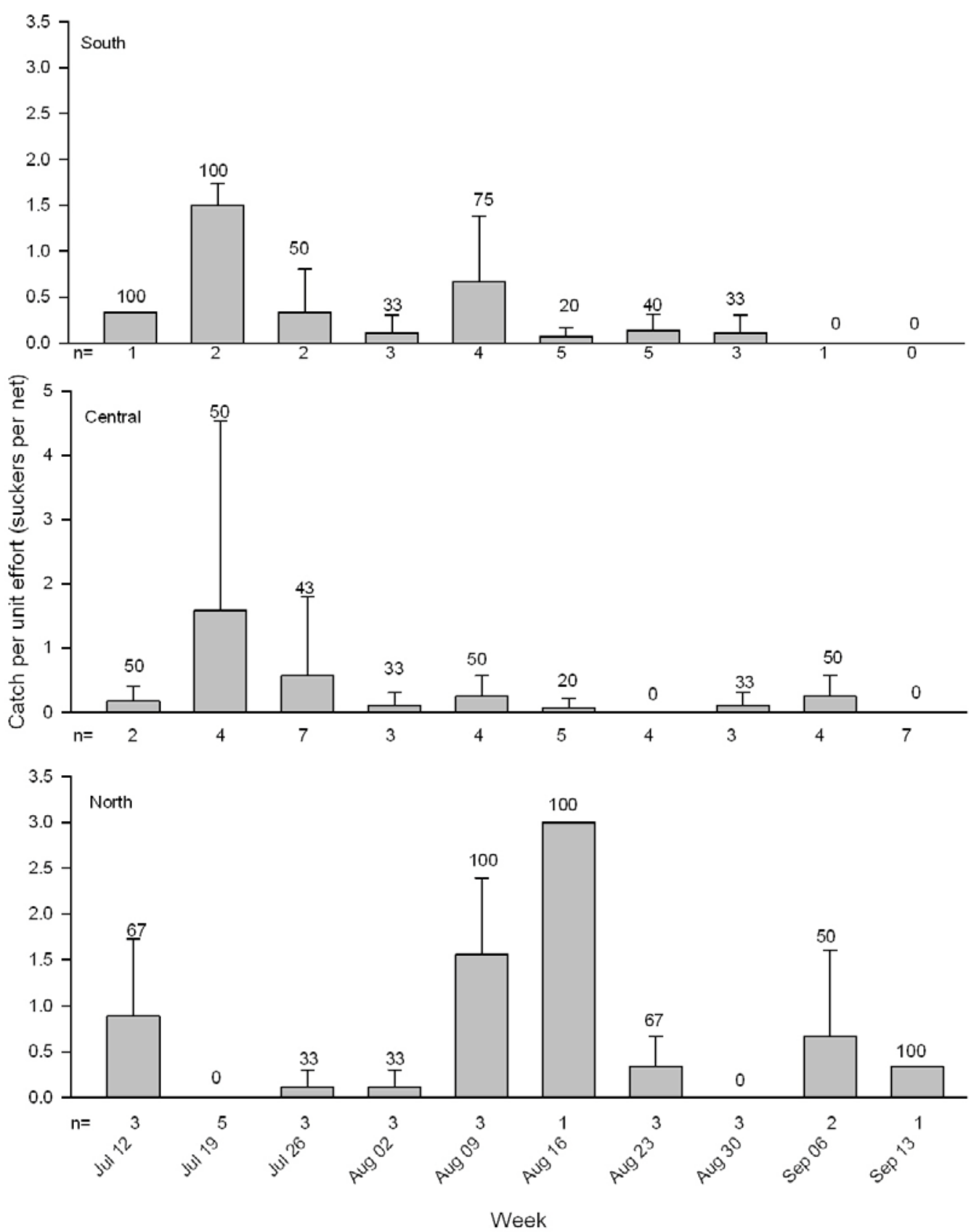

Figure 10. Mean ( \pm SD) weekly catch per unit effort (suckers per net) for age-0 suckers caught in trap nets in three near-shore areas (fig. 1) of Upper Klamath Lake, Oregon, between July 12 and September 16, 2009. Sample sites considered to be near-shore were within 100 meters of shore. The percentages of sites at which at least one sucker was caught and numbers of sites sampled each week are given above and below the $x$-axis, respectively. Dates are given for the Sunday that started each week. Note the different $y$ axis scale on the central strata CPUE plot. 


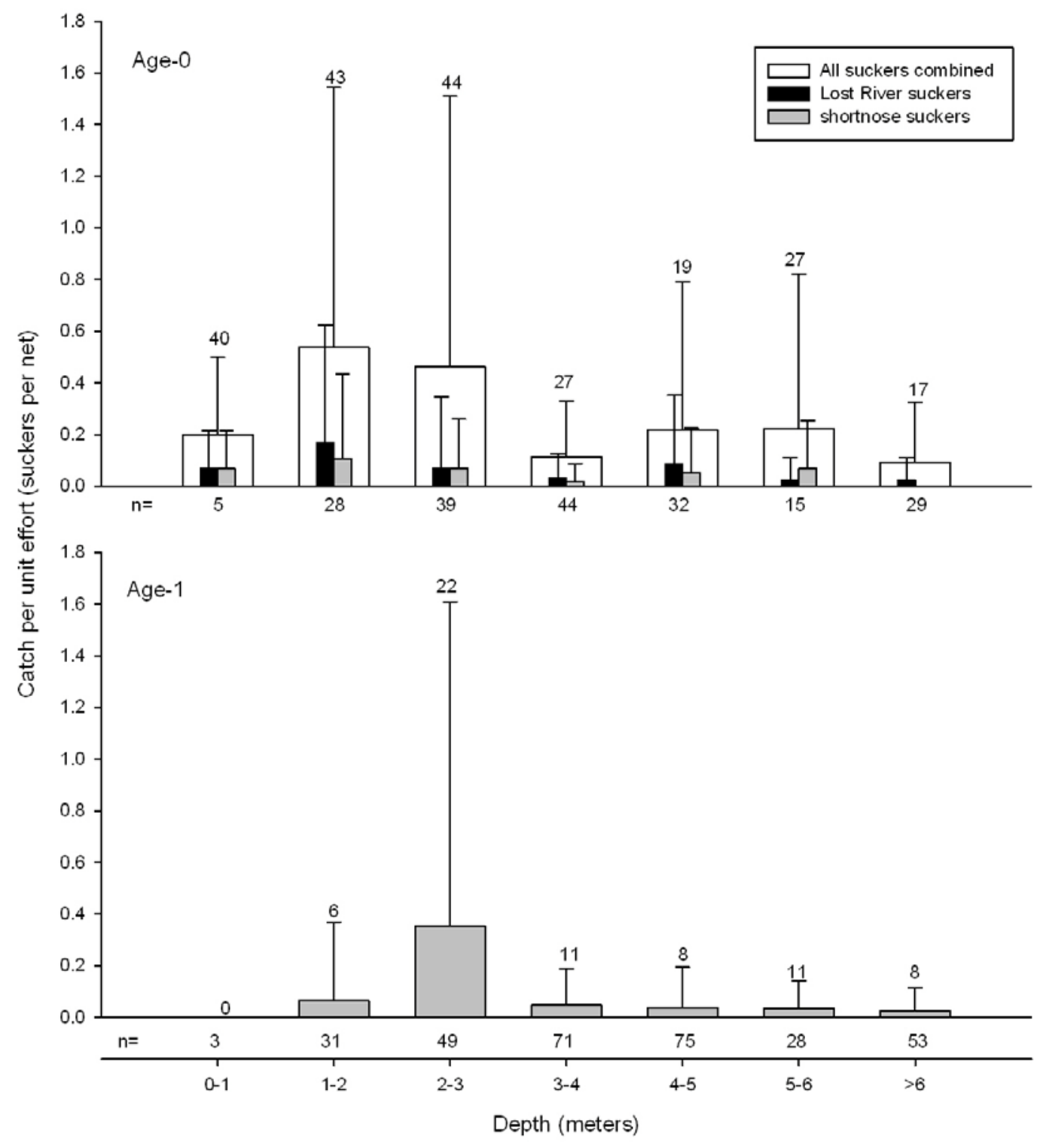

Figure 11. Mean $( \pm S D)$ catch per unit effort (CPUE: suckers per net) by $1.0 \mathrm{~m}$ depth bins for age-0 (top) and age-1 (bottom) suckers caught in Upper Klamath Lake, Oregon. The sample sites used in preparation of this figure were limited to those sampled between the first and last capture of suckers in each age group. Therefore, for age- 0 suckers only sites sampled between July 12 and September 16 were used and for age-1 suckers, only sites sampled between May 17 and September 5 were used. The percentages of sites in each depth category at which at least one sucker was caught are given (above the bars) and the number of sites sampled in each depth category (below the $x$-axis). One in every three age-0 suckers were sacrificed and identified to species. The CPUE for all sacrificed age-0 suckers, and those identified to species is shown (top). 


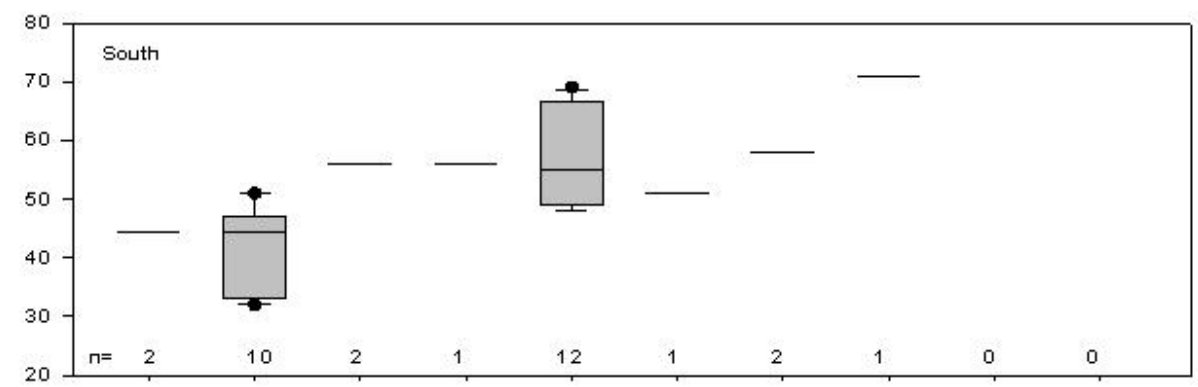

EXPLANATION

- Outlier

T 90" percentile

$75^{\text {th }}$ percentile

Median

$25^{\text {th }}$ percentile

$10^{\text {sn }}$ percentile
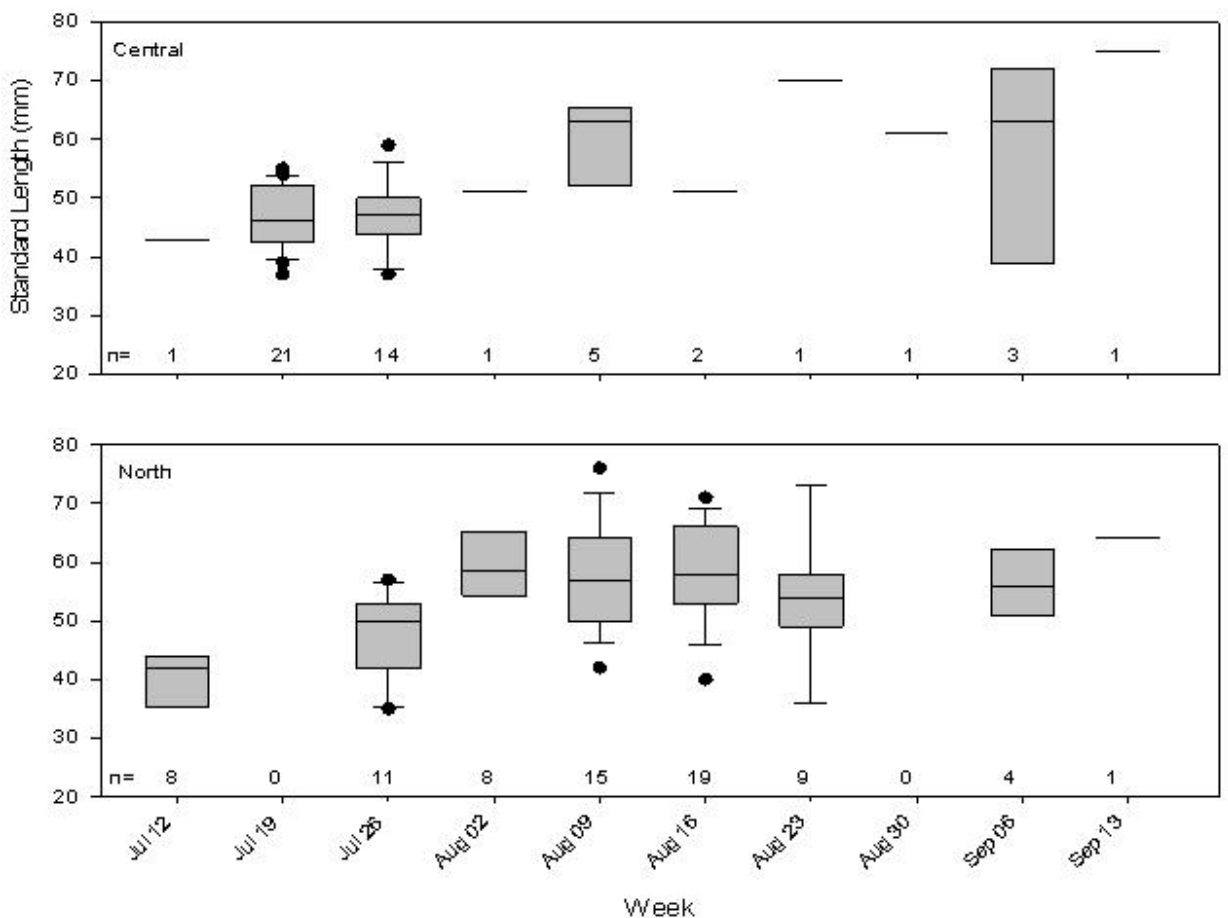

Figure 12. Standard length $(\mathrm{mm})$ of age-0 suckers caught in trap net sampling in three areas (fig. 1) of Upper Klamath Lake, Oregon, between July 12 and September 16, 2009. The numbers of age-0 suckers caught each week and strata that were used in the creation of the boxplots are given along the $x$-axis. 

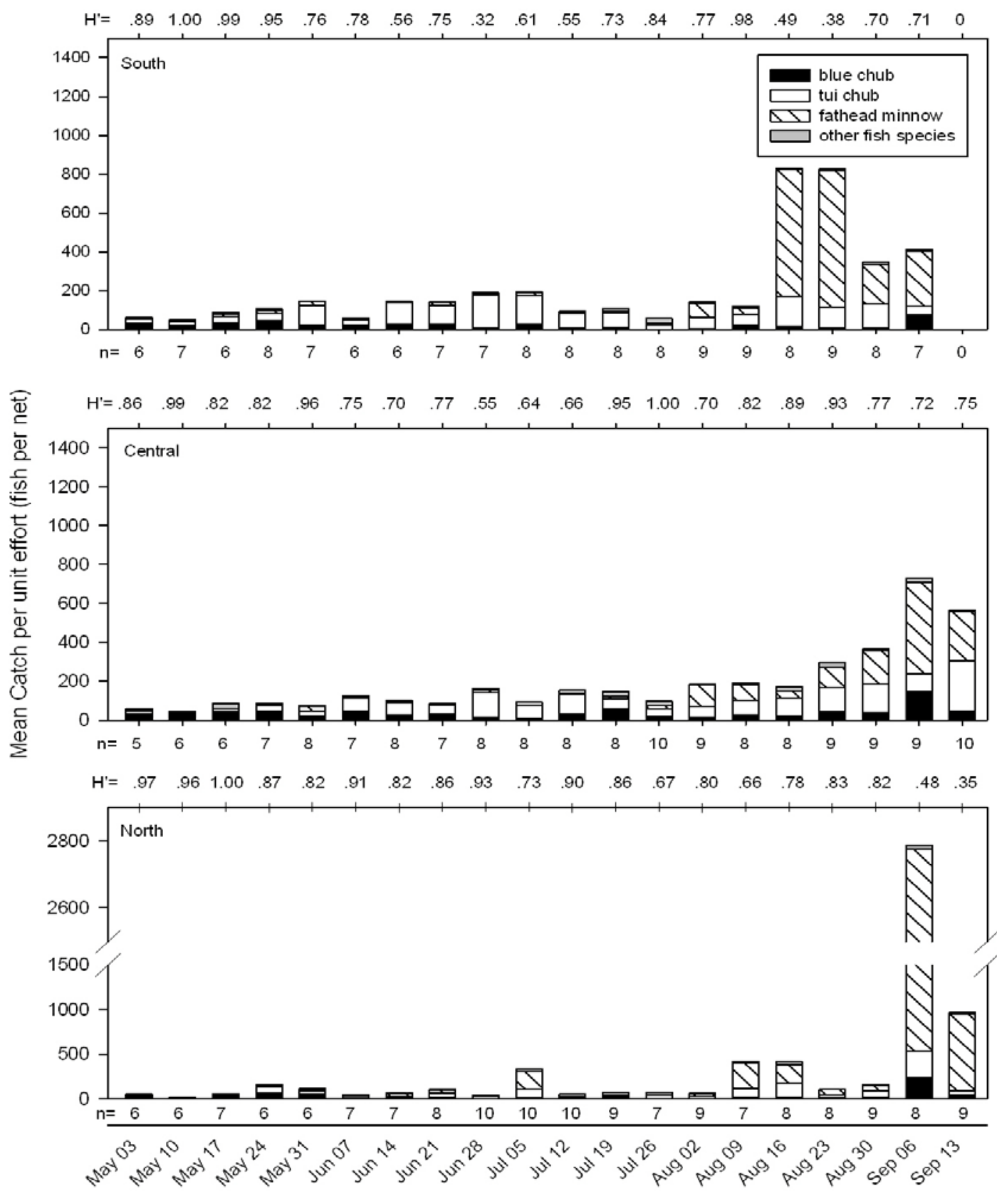

Week

Figure 13. Mean weekly catch per unit effort (fish per net) of fish other than sucker species captured in trap nets set overnight in three areas of Upper Klamath Lake, Oregon (fig. 1). Species richness, the number of species collected in each strata, and week are shown below the $x$ axis. The Shannon-Wiener diversity index was calculated for each strata and week, and standardized by dividing each value by the highest index value in each week and strata. Standardized index values $\left(\mathrm{H}^{\prime}\right)$ are shown above each graph. The grouping 'other fish species' includes yellow perch, brown bullhead, Upper Klamath marbled sculpin, slender sculpin, Klamath Lake sculpin, pumpkinseed, largemouth bass, speckled dace, redband trout, and lamprey species. 
Table 1. Number of sites successfully sampled for juvenile fish in three seasons and in six strata in Upper Klamath Lake, Oregon, 2009.

[Sampling strata are shown in figure 1. The number of sites at which two, three, or four nets were set in each season is given. The seasons are defined as Spring (May 3-June 20), Mid-Summer (June 21-August 8), and Late Summer (August 9-September 17). Five nets set during 2009 (2 North Off-shore, 1 Central Off-shore, 1 South Off-shore, 1 South Near-shore) failed to effectively sample fish and were removed from the dataset]

\begin{tabular}{|c|c|c|c|c|c|}
\hline \multirow[b]{2}{*}{ Season } & \multirow[b]{2}{*}{ Strata } & \multicolumn{3}{|c|}{ Number of nets } & \multirow[b]{2}{*}{ Total sites } \\
\hline & & 2 & 3 & 4 & \\
\hline \multirow{6}{*}{ Spring } & Central Near-shore & 0 & 18 & 9 & 27 \\
\hline & Central Off-shore & 2 & 15 & 13 & 30 \\
\hline & North Near-shore & 0 & 12 & 10 & 22 \\
\hline & North Off-shore & 0 & 11 & 8 & 19 \\
\hline & South Near-shore & 1 & 11 & 8 & 20 \\
\hline & South Off-shore & 0 & 14 & 3 & 17 \\
\hline Spring Total & & 3 & 81 & 51 & 135 \\
\hline \multirow{6}{*}{ Mid-Summer } & Central Near-shore & 0 & 13 & 11 & 24 \\
\hline & Central Off-shore & 0 & 15 & 9 & 24 \\
\hline & North Near-shore & 0 & 11 & 11 & 22 \\
\hline & North Off-shore & 0 & 10 & 5 & 15 \\
\hline & South Near-shore & 0 & 10 & 5 & 15 \\
\hline & South Off-shore & 0 & 9 & 4 & 13 \\
\hline \multirow{2}{*}{$\begin{array}{l}\text { Mid-Summer } \\
\text { Total }\end{array}$} & & & & & \\
\hline & & 0 & 68 & 45 & 113 \\
\hline \multirow{6}{*}{ Late Summer } & Central Near-shore & 0 & 17 & 13 & 30 \\
\hline & Central Off-shore & 0 & 19 & 12 & 31 \\
\hline & North Near-shore & 0 & 11 & 5 & 16 \\
\hline & North Off-shore & 0 & 15 & 6 & 21 \\
\hline & South Near-shore & 0 & 12 & 9 & 21 \\
\hline & South Off-shore & 0 & 9 & 6 & 15 \\
\hline \multirow[t]{2}{*}{$\begin{array}{l}\text { Late Summer } \\
\text { Total }\end{array}$} & & & & & \\
\hline & & 0 & 83 & 51 & 134 \\
\hline Total & & 3 & 232 & 147 & 382 \\
\hline
\end{tabular}


Table 2. Number of nets successfully fished and age-1 and age-2 suckers captured per net in six strata in Upper Klamath Lake, Oregon, between May 17 and September 5, 2009.

[Sampling strata are shown in figure 1. Trap nets were set overnight in six strata including near and off-shore strata in the south, central, and north portions of the lake. Near-shore sites were within $100 \mathrm{~m}$ of shore, whereas off-shore sites were more than $100 \mathrm{~m}$ from shore. At a subset of our sites, we set nets with mesh too large to capture age-1 suckers, therefore, they were only included in the age-2 CPUE analysis]

\begin{tabular}{lcccc}
\hline & & & \multicolumn{2}{c}{ Suckers per net } \\
\cline { 3 - 5 } \multicolumn{1}{c}{ Strata } & Number of & Number of & & \\
age-1 nets & age-2 nets & Age-1 & Age-2 \\
\hline South Near-shore & 138 & 156 & 0.20 & 0.000 \\
South Off-shore & 108 & 119 & 0.02 & 0.017 \\
Central Near-shore & 183 & 207 & 0.22 & 0.005 \\
Central Off-shore & 213 & 237 & 0.02 & 0.004 \\
North Near-shore & 153 & 177 & 0.10 & 0.011 \\
North Off-shore & 135 & 152 & 0.01 & 0.007 \\
Tributaries & 210 & 237 & 0.13 & 0.013 \\
\hline
\end{tabular}


Publishing support provided by the U.S. Geological Survey

Publishing Network, Tacoma Publishing Service Center

For more information concerning the research in this report, contact the Director, Western Fisheries Research Center U.S. Geological Survey, 6505 NE 65th Street Seattle, Washington 98115

http://wfrc.usgs.gov/ 


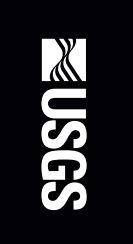

